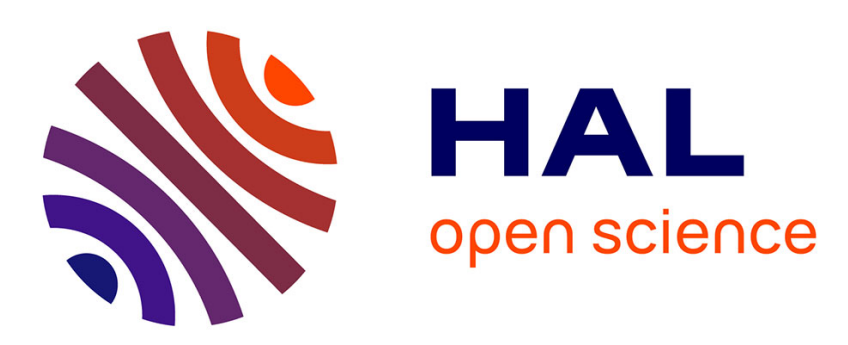

\title{
Precipitation Composition and Its Variability in the Southern Indian Ocean' Amsterdam Island, 1980-1987
}

\author{
J. L Moody, A. a P Pszenny, A. Gaudry, W. C Keene, J. N Galloway, G.
} Polian

\section{- To cite this version:}

J. L Moody, A. a P Pszenny, A. Gaudry, W. C Keene, J. N Galloway, et al.. Precipitation Composition and Its Variability in the Southern Indian Ocean' Amsterdam Island, 1980-1987. Journal of Geophysical Research, 1991, 96 (D11), pp.20769. 10.1029/91JD01921 . hal-03583323

\section{HAL Id: hal-03583323 \\ https://hal.science/hal-03583323}

Submitted on 21 Feb 2022

HAL is a multi-disciplinary open access archive for the deposit and dissemination of scientific research documents, whether they are published or not. The documents may come from teaching and research institutions in France or abroad, or from public or private research centers.
L'archive ouverte pluridisciplinaire HAL, est destinée au dépôt et à la diffusion de documents scientifiques de niveau recherche, publiés ou non, émanant des établissements d'enseignement et de recherche français ou étrangers, des laboratoires publics ou privés. 


\title{
Precipitation Composition and Its Variability in the Southern Indian Ocean: Amsterdam Island, 1980-1987
}

\author{
J.L. Moody, A.A.P. Pszenny, ${ }^{1}$ A. Gaudry, ${ }^{2}$ W.C. KeEne, \\ J.N. Galloway, and G. Polian ${ }^{2}$ \\ Department of Environmental Sciences, University of Virginia, Charlottesville
}

\begin{abstract}
Event precipitation samples have been collected on Amsterdam Island (37 $\left.47 \mathrm{~S}, 77^{\circ} 31^{\prime} \mathrm{E}\right)$ from May 1980 through January 1987 and analyzed for $\mathrm{SO}_{4}{ }^{2}, \mathrm{NO}_{3}^{-}, \mathrm{Cr}, \mathrm{Na}^{+}, \mathrm{Mg}^{++}, \mathrm{K}^{+}, \mathrm{Ca}^{++}, \mathrm{H}^{+}$, $\mathrm{HCOQ}_{4}$, and $\mathrm{CH}_{3} \mathrm{COQ}$. The objective of this paper is to assess the processes which influence variability in the chemical composition of precipitation at this remote marine site. Back trajectories and gas phase ${ }^{222} \mathrm{Rn}$ measurements were used to identify source regions and their relative contributions to precipitation composition. The technique of cluster analysis was applied to trajectory data as a method for determining to what degree different atmospheric flow patterns influence variability in the observed composition. The dominant source regions for chemical deposition were found to be Madagascar and/or S.E. Africa and the ocean region north and east of Amsterdam Island. A strong seasonal signal in the precipitation composition is illustrated. Processes which influence variability in the chemical composition include the following: seasonality in the source strength of biogenic precursors for non-sea-salt (nss) $\mathrm{SO}_{4}{ }^{=}, \mathrm{NH}_{4}{ }^{+}$and carboxylic acids; seasonality in biomass-burning continental sources for the concentration of $\mathrm{NO}_{3}{ }^{-}$and a portion of nss $\mathrm{Cr}$; and variations in source region driven by daily changes in meteorology, as well as seasonal and annual differences in transport and removal patterns. In addition, interannual differences in nss $\mathrm{SO}_{4}{ }^{*}$ concentration appear to be related to fluctuations in large-scale circulation patterns as defined by the Southern Oscillation.
\end{abstract}

\section{Introduction}

The Global Precipitation Chemistry Project (GPCP) collects precipitation samples for chemical analysis at several remote continental and marine locations around the globe [Galloway et al., 1982]. The goals of the GPCP at Amsterdam Island are to assess the composition of precipitation in a marine region remote from the dominant influence of fossil-fuel combustion and to differentiate the relative importance of biogeochemical factors which regulate precipitation chemistry in such a region. By design the GPCP seeks to evaluate the background or natural composition of precipitation and to infer the composition of preindustrial age precipitation. In a preliminary analysis, Galloway and Gaudry [1984] have shown that there is substantial variability in the chemical composition of precipitation on Amsterdam Island from event to event. Therefore before interpreting these data as baseline measurements of precipitation quality, it is essential to understand what factors influence this variability.

The basic objectives of this paper are to determine the average composition of precipitation and its variability and to identify processes that could contribute to the observed variability. The underlying processes considered are emission, transformation, transport, and deposition. They

\footnotetext{
Tow at National Oceanic and Atmospheric Administration, Atlantic Oceanographic and Meteorological Laboratories, Miami, Florida.

${ }^{2}$ Centre des Faibles Radioactivités, Laboratoire Mixte CNRS/CEA, Gif-sur-Yvette, Cedex, France.
}

Copyright 1991 by the American Geophysical Union.

Paper number $91 \mathrm{JD} 01921$.

0148-0227/91/91JD-01921\$05.00 can contribute to variability in a number of ways, including seasonality in source strength (emission) and atmospheric reactivity (transformation), variations in source region driven by daily changes in meteorology (emission and transport), and seasonal or annual differences in trajectories and removal patterns (transport and deposition).

\section{Methods}

\subsection{Precipitation Samples}

Amsterdam Island, Territoire des Terres Australes et Antarctiques Francaises, is a small $(9 \mathrm{~km}$ by $5 \mathrm{~km})$ island located in the prevailing westerlies of the southern hemispheric Indian Ocean (37 47' S, $77^{\circ} 31^{\prime}$ E) $5000 \mathrm{~km}$ from both the African and Australian continents, $3400 \mathrm{~km}$ from Madagascar. Its flora and geology are described by Gaudry et al. [1983]. The island fauna includes seasonal populations of fur seals and seabirds as well as a permanent population of bovine cattle. The seals are uniformly distributed along the coast [Roux and Hes, 1984]. Large colonies of penguins (50,000 pairs) and albatross ( 37,000 pairs) have been described by Jouventin et al. [1983]. They are located only on the southwest shore of the island as noted in Figure 1.

Precipitation samples were collected between May 1980 and January 1987 using polyethylene funnels and bottles at a site $2 \mathrm{~km}$ southeast of the northwest shoreline, at an elevation of $200 \mathrm{~m}$ above sea level (see Figure 1). Logistical constraints limited sampling to approximately one quarter of all events. The $\mathrm{pH}$ was measured on site in aliquots of all samples of sufficient volume [Galloway et al., 1982]. After collection, samples were spiked with $\mathrm{CHCl}_{3}$ to prevent microbial activity [Keene et al., 1983; 


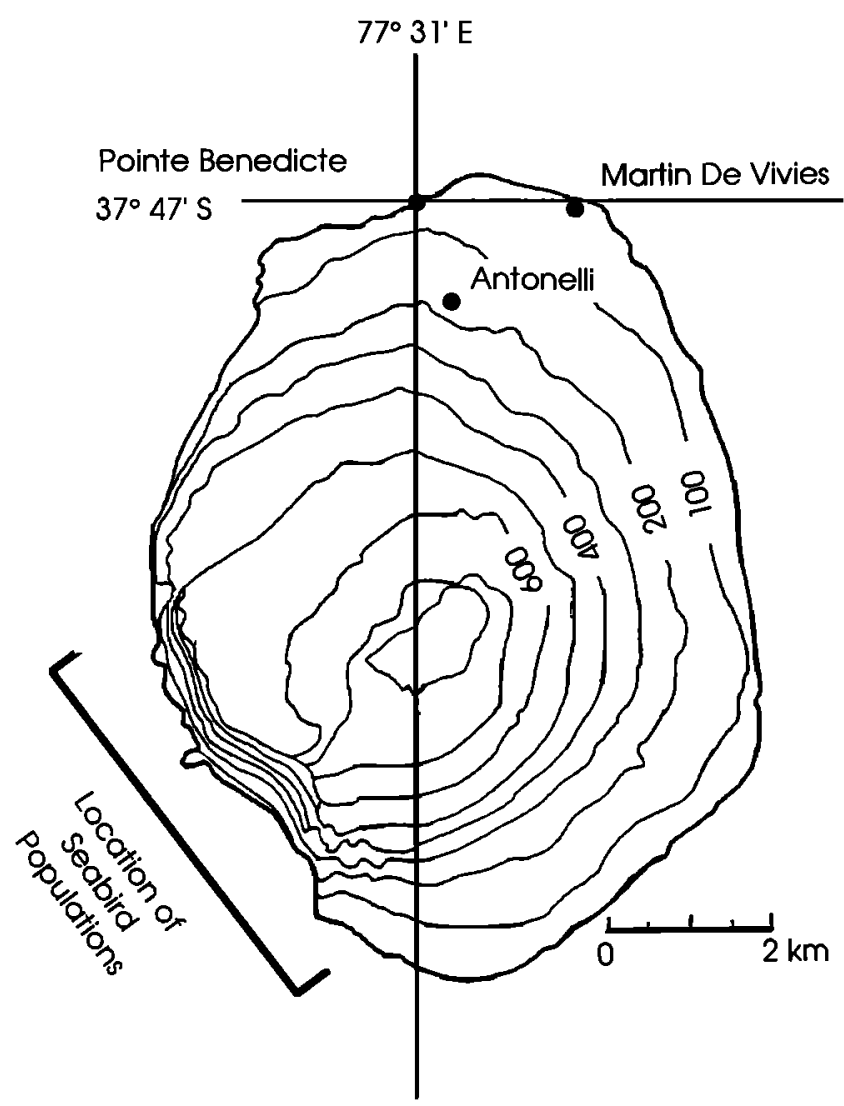

Fig. 1. Map of Amsterdam Island illustrating site location (Antonelli), elevation contours, and location of seasonal seabird populations.

Keene and Galloway, 1984], stored in the dark, and shipped to the University of Virginia for chemical analysis. Details of sampling and analytical and quality assurance procedures are given by Galloway and Gaudry [1984]. Excess or non-sea-salt concentrations of $\mathrm{SO}_{4}{ }^{=}, \mathrm{Cr}, \mathrm{Mg}^{++}$, $\mathrm{Ca}^{++}$, and $\mathrm{K}^{+}$were calculated as described by Keene et al. [ 1986 ] using $\mathrm{Na}^{+}$as the reference species and Wilson's [1975] composition of seawater.

\subsection{Air Mass Tracer Methods}

2.2.1. Radon. Radon 222 is a radioactive gas which is continuously released from the soil by the decay of radium 226. Typical ground level continental concentrations of ${ }^{222} \mathrm{Rn}$ are on the order of 80 to $200 \mathrm{pCi} / \mathrm{m}^{3}$ [Lambert et $a l ., 1982$ ]. With a half-life of 3.8 days, ${ }^{222} \mathrm{Rn}$ can be measured at remote marine locations as a useful tracer of continental air. Over the southern Indian Ocean this concentration is reduced by dilution and radioactive decay to a value of the order of $0.5 \mathrm{pCi} / \mathrm{m}^{3}$, which Polian et al. [1986] describes as characteristic of the "pure marine atmosphere."

The concentration of ${ }^{222} \mathbf{R n}$ was measured at Pointe Benedicte (Figure 1) at 2-hour intervals using alphascintillation assay of its short-lived daughters collected on filters [Lambert et al., 1970]. On Amsterdam Island, baseline concentrations were of the order of 0.5-1.0
$\mathrm{pCi} / \mathrm{m}^{3}$. Radonic storms, as defined by Lambert et al. [1970], are episodes when ${ }^{222}$ Rn concentrations increase rapidly to over $4 \mathrm{pCi} / \mathrm{m}^{3}$. Using other measures (surface wind speed and direction and $\mathrm{CO}_{2}$ concentration), periods when local island emissions of ${ }^{222} \mathrm{Rn}$ could influence the sample were classified separately.

Four different categories of events were defined using these data. Events with ${ }^{222} \mathrm{Rn}$ above $4 \mathrm{pCi} / \mathrm{m}^{3}$ and surface winds which did not cross the island (i.e., arriving from the marine sector between $250^{\circ}$ and $50^{\circ}$ ) were classified "remote continental." Events with background concentrations $\left(0.5 \mathrm{pCi} / \mathrm{m}^{3}\right)$ arriving from the marine sector were classified "remote oceanic." Events with surface winds less than $4 \mathrm{~m} / \mathrm{s}$ or winds from directions which traverse the island that also had radon and $\mathrm{CO}_{2}$ concentrations indicating a local influence were classified "local." Finally, all other events with measureable ${ }^{222} \mathbf{R}$ concentrations were considered a mixture of weak remote continental, local and remote oceanic air, and were classified "mixed." These four classes were then analyzed for significant differences in distributions of chemical concentration and deposition; results are reported in section 3.4.

2.2.2. Back traj ectories. Ten-day back, isobaric trajectories were calculated at 850 mbar [Harris, 1982] using analyzed wind fields from a global, dynamic, nine-layer primitive equation model [Stackpole, 1978]. In this study, cluster analysis of trajectories [Moody, 1986] was used to identify precipitation events which occurred under conditions of similar transport to Amsterdam Island. It is a useful technique for quantifying the relative influence of atmospheric transport on precipitation composition at both marine and continental locations [Moody and Galloway, 1988; Moody and $S$ amson, 1989]. It has also proved useful for characterizing the general flow climatology of a site [Harris and Kahl, 1990].

Cluster variables were trajectory endpoints which parameterize the wind speed and direction at 3-hour intervals. To minimize the number of incomplete trajectories, only trajectory endpoint data representing air parcel locations out to 5 days upwind of Amsterdam Island were clustered. Since errors in the trajectory location are magnified as a function of time back [Kahl and Samson, 1986], this is also a conservative cutoff which reduces the risk of using calculated trajectories significantly divergent from the true (but unknown) transport.

A hierarchical clustering algorithm, using an Euclidean similarity measure, and designed to minimize within-group variance [Ward's method] was applied [Gordon 1981; Romesburg 1984], as described by Moody and Galloway [1988]. Because the hierarchical method has the drawback of permanently assigning trajectories to a cluster, and Ward's method in special situations tends to create clusters of similar size [Kalkstein et al. [1987], a second method was applied to ensure a relatively optimal definition of distinct transport patterns. An iterative cluster algorithm [Norusis, 1985] was run with 
initial centers chosen randomly for the number of clusters identified using the hierarchical method. This method was applied repeatedly until the iterations converged, and the cluster means did not change. This was identified as the optimal cluster assignment of trajectories. Comparing the hierarchical and iterative methods, the only differences were in the assignment of trajectories on the periphery of hierarchically defined clusters. This suggests that the results are relatively robust and that there are in fact recurring, discernible patterns of atmospheric transport to Amsterdam Island.

Clustering and hypothesis testing were performed using the SPSS , package [Norusis, 1985]. Distributions of precipitation chemistry concentration and deposition do not typically meet the assumptions of normality and homoscedasticity required by parametric tests. Therefore all hypothesis tests employed nonparametric statistics [Conover, 1980].

\subsection{Data Subsets}

Samples were removed from the original data set of 206 for a variety of reasons, including ion balances exceeding $\pm 15 \%$, insufficient volume for complete inorganic analyses, and no precipitation gauge data available (Table 1). This resulted in a quality-assured data set of 179 precipitation events with complete inorganic analyses. After August 1981 the concentrations of $\mathrm{HCOQ}$ (HCOOH $+\mathrm{HCOO}$ ) and $\mathrm{CH}_{3} \mathrm{COOH}_{4}\left(\mathrm{CH}_{3} \mathrm{COOH}+\mathrm{CH}_{3} \mathrm{COO}^{-}\right)$were

TABLE 1. Description of Data Subsets

\begin{tabular}{ll}
\hline Description & Number \\
\hline
\end{tabular}

Total number of samples arriving

at UVA

a) Samples not meeting $Q A / Q C$ criteria

b) Samples with no precipitation amount recorded

c) Samples with incomplete chemical analyses

Complete QA/AC inorganic data

a) Samples with no organic analysis

Complete QA/QC inorganic plus organic data

Complete QA/QC inorganic data plus trajectory available for defining transport path of event

Complete QA/QC inorganic data plus radon measurement available for defining radon classification analyzed [Keene et al., 1983] resulting in a complete organic/inorganic data set of 142 samples. Two other data sets include samples with complete inorganic data and good trajectories and samples with complete inorganic data and $\mathrm{a}^{222} \mathrm{Rn}$ measurement.

\section{Results And Discussion}

Galloway and Gaudry [1984], using a data set of 66 samples, reported that Amsterdam Island precipitation was made up of two components, dilute seawater and a small but significant acid component. While the basic composition of precipitation on Amsterdam Island remains relatively unchanged, the greater number of samples included in this study allows us to address sources of variation. Table 2 compares the volume weighted average (VWA) concentrations for total and non-sea-salt fractions of measured constituents for all 179 precipitation events in this data set with the 66 samples presented by Galloway and Gaudry [ 1984]. For this earlier work, $\mathrm{Mg}^{++}$was used to calculate non-sea-salt components. While in some instances $\mathrm{Mg}^{+\boldsymbol{t}}$ may be a better tracer of sea salt [Keene, et al. 1986], a reduced major axis regression analysis indicated no significant difference in the observed slope of the $\mathrm{Mg}^{++}: \mathrm{Na}^{+}$ratio and the seawater ratio of 4.41 [Wilson, 1975] or between the regression intercept and 0. This suggests no significant enrichment of either $\mathrm{Na}^{+}$or $\mathrm{Mg}^{++}$, and $\mathrm{Na}^{+}$was used as the reference species in this work. By comparison a regression analysis of nss $\mathrm{Cr}^{-}$

TABLE 2. Volume Weighted Means $(n=179)$ of Ions in Sea-salt and Non-Sea-Salt Components of Amsterdam Island Rain ( $\mu \mathrm{eq} / \ell$ )

\begin{tabular}{lrrr}
\hline & $\begin{array}{c}\text { Total } \\
\text { Non- } \\
\text { Sea-salt }\end{array}$ & $\begin{array}{l}\text { Non- } \\
\text { Sea-salt }\end{array}$ & $\begin{array}{l}\text { Non- } \\
\text { Sea-salt } \\
(\mathrm{G \& G})^{*}\end{array}$ \\
\hline $\mathrm{H}^{+}$ & 8.4 & 8.4 & 8.8 \\
$\mathrm{SO}_{4}{ }^{+}$ & 37.2 & 4.8 & 4.9 \\
$\mathrm{NO}_{3}{ }^{+}$ & 1.6 & 1.6 & 1.3 \\
$\mathrm{NH}_{4}^{+}$ & 2.4 & 2.4 & 1.8 \\
$\mathrm{RCOO}^{+}$ & 3.7 & 3.7 & 2.2 \\
$\mathrm{Cr}^{+}$ & 317.6 & 4.3 & 2.5 \\
$\mathrm{Na}^{+}$ & 268.8 & $0.0^{r}$ & 4.8 \\
$\mathrm{Mg}^{++}$ & 60.3 & -0.6 & 0.0 \\
$\mathrm{~K}^{+}$ & 5.9 & 0.1 & 0.0 \\
$\mathrm{Ca}^{++}$ & 12.1 & 0.4 & -0.3 \\
\hline
\end{tabular}

*Galloway and Gaudry [1984].

$112{ }^{\mathrm{t}}$ Total carboxylic acids measured $\mathrm{HCOO}_{\mathrm{t}}+\mathrm{CH}_{3} \mathrm{COQ}$ ).

'By definition as reference species. 
versus the reference species $\mathrm{Na}^{+}$indicates both a slope significantly different from seawater and a positive intercept suggesting a real source of nss $\mathrm{Cr}$ in Amsterdam Island precipitation.

On average, nSs $\mathrm{SO}_{4}{ }^{2}$ and nss $\mathrm{Cr}$ are the most abundant anions and the precipitation is weakly acid, with a VWA
pH of 5.1. However, there is considerable variability underlying this average composition. This variability is discussed in the next several sections. First, seasonal signals in the data are illustrated, the potential contribution of local sources is considered, and seasonality is discussed by species, then interannual differences in

TABLE 3. Comparison of Per Event Concentration, Per Event

Deposition, and Per Event Precipitation Amount by Season,

Southern Hemisphere Winter (April-September), and

Southern Hemisphere Summer (October-March)

\begin{tabular}{|c|c|c|c|}
\hline & Winter & Summer & Significance \\
\hline \multicolumn{4}{|c|}{ Average Per Event Concentration $\mu \mathrm{eq} / \ell$} \\
\hline nss $\mathrm{SO}_{4}{ }^{2}$ & 4.3 & 8.0 & * \\
\hline nss $\mathrm{NO}_{3}-$ & 1.9 & 2.3 & \\
\hline $\mathbf{H}_{4}$ & 9.4 & 12.4 & * \\
\hline $\mathrm{NH}_{4+}$ & 2.8 & 4.4 & * \\
\hline $\mathrm{HCOQ}_{\mathrm{t}}$ & 3.6 & 5.8 & * \\
\hline $\mathrm{CH}_{3} \mathrm{COO}_{3}$ & 1.3 & 2.2 & * \\
\hline $\mathrm{Na}^{+}$ & 535.7 & 324.7 & * \\
\hline nss $\mathrm{Cr}$ & 4.8 & 10.9 & \\
\hline nss $\mathrm{Ca}^{+}$ & 1.1 & 1.6 & \\
\hline nss $\mathrm{Mg}^{++}$ & -2.6 & -0.1 & \\
\hline nss $\mathbf{K}^{+}$ & 0.1 & 0.4 & \\
\hline
\end{tabular}

Average Per Event Deposition, $\mu \mathrm{eq} / \mathrm{m}^{2}$

Dnss $\mathrm{SO}_{4-}$

26.0

67.0

$\mathrm{DNO}_{3-}$

13.0

18.0

DH $^{+}$

65.0

95.0

$\mathrm{DNH}_{4+}$

16.0

31.0

DHCOO

17.0

33.0

$\mathrm{DCH}_{3} \mathrm{COQ}$

5.4

15.0

$\mathrm{DNa}^{+}$

308.4

191.0

Dnss Cr

30.0

52.0

Dnss $\mathrm{Ca}^{++}$

1.0

7.0

Dnss $\mathbf{M g}^{++}$

$-10.0$

0.

Dnss K

$-1.0$

2.0

Average Per Event Precipitation Amount, cm

ppt

0.92

0.96

"Seasonal differences significant at $95 \%$ confidence level.

${ }^{t} \mathrm{n}=179$, except for organics, $\mathrm{n}=142$ (summer, $\mathrm{ppt}=0.99 \mathrm{~cm}$ and winter, $\mathrm{ppt}=0.88$ $\mathrm{cm})$. 
precipitation composition are discussed. Finally, variability related to different transport patterns is considered.

\subsection{Seasonal Variability}

Seasonal variability is evident in the Amsterdam Island precipitation chemistry data. A Mann-Whitney test was performed to identify distributional differences between two broad seasons (summer, October-March and winter, April-September) in per event concentration, per event deposition, and per event precipitation amount (Table 3). There was no significant difference in per event amount between seasons, but several chemical differences were identified. With the exception of nss $\mathrm{Cr}$ and nss $\mathrm{SO}_{4}{ }^{2}$, the concentrations of non-sea-salt constituents are low relative to uncertainties in the data; therefore determining sources of variation for these components is difficult.

A plot of VWAs by month for the ions $\mathrm{SO}_{4}{ }^{2}, \mathrm{H}^{+}, \mathrm{NO}_{3}^{-}$, and $\mathrm{NH}_{4}{ }^{+}$indicates relative concentrations and illustrates that all concentrations increase in austral spring (Figure 2). The peak for $\mathrm{NO}_{3}{ }^{-}$is confined to this period, however, whereas the other species remain elevated for the rest of the warm season.

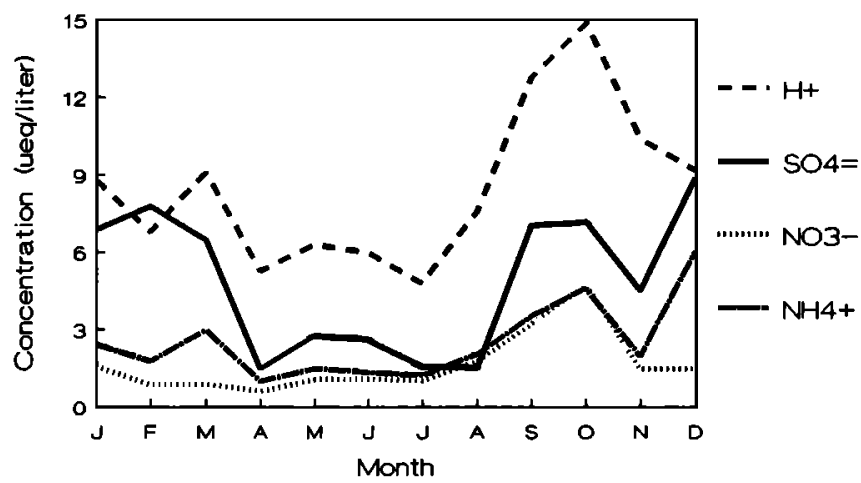

Fig. 2. Volume weighted averages by month for entire Amsterdam Island data set 1980-1987 $(n=179)$. The number of events averaged in each month is noted by species in Figure 3.

Monthly box plots of per event deposition, which account for differences in event volume for $\mathrm{H}^{+}$, nss $\mathrm{SO}_{4}{ }^{2}$, $\mathrm{NO}_{3}^{-}, \mathrm{NH}_{4}^{+}$, nss $\mathrm{Cl}, \mathrm{HCOO}_{\mathrm{t}}$, and $\mathrm{CH}_{3} \mathrm{COO}_{\mathrm{t}}$ reveal a seasonal cycle similar to the VWA concentrations (Figure 3 ). With the exception of $\mathrm{NO}_{3}{ }^{-}$and nss $\mathrm{Cr}$, median per event depositions increase in austral spring, remain high throughout the summer, and decrease in April or May, at the beginning of austral autumn. By comparison $\mathrm{NO}_{3}^{-}$ deposition exhibits relatively less seasonal variability. A monthly box plot of $\mathrm{NO}_{3}^{-}$concentration (Figure 4) indicates a more pronounced spring peak. These results suggest higher spring $\mathrm{NO}_{3}^{-}$concentrations are at least partially influenced by somewhat lower and less variable precipitation amounts for the months July through October (Figure 3h).

The only species exhibiting higher concentrations in the months April through September is $\mathrm{Na}^{+}$. Since the uncertainty associated with nss components is in part a function of the magnitude of the reference species $\left(\mathrm{Na}^{+}\right)$, we would expect uncertainties in these calculated values to be greater during the cold season. This may account for some of the negative concentrations and depositions of nss $\mathrm{SO}_{4}{ }^{=}$and nss $\mathrm{Cl}$ (Figure 3b) in the winter months. The uncertainty associated with an individual measurement may result in the calculation of a negative concentration; however the central tendency of the population should remain unbiased by this uncertainty [Keene et al., 1986]. In the case of nss $\mathrm{Cr}$, however the fact that even the median values for several months are negative may be indicative of a real chemical deficit. Processes which could produce this deficit are discussed in section 3.1.5.

The increased concentrations and depositions observed during austral spring are likely the result of a combination of large-scale circulation and source strength (transport and emission) factors. The strength and location of the southern Indian Ocean subtropical anticyclone favors flow from the west during austral winter with an increasingly northwest component in early spring [Taljaard and Van Loon, 1984]. Consistent with this, an analysis of 10 years of isobaric trajectories indicates that high speed transport (average winds greater than $40 \mathrm{~km} / \mathrm{hr}$ ) from the northwest is most frequent from June through October [J. $M$. Miller, personal communication, 1990]. These analyses suggest the greatest potential for continental air from Africa and Madagascar reaching Amsterdam Island is in late winter and early spring. In summer the subtropical high pressure weakens and the center migrates eastward, reducing high speed transport from the west and favoring flow with a more northerly component arriving on Amsterdam Island [Ramage, 1984].

Although transport from continental regions is favored during late winter/early spring, removal mechanisms are also seasonally dependent. Precipitation is more frequent in the winter with an average of 22.6 days per month (April-September) recording at least $0.1 \mathrm{~mm}$ of rain, while in the months of October-March this frequency drops to 17.5 days. Greater wind speeds also occur from April to September with an average of 18 days per month recording wind speeds greater than $16 \mathrm{~m} / \mathrm{sec}$, while from October to March 10.8 days occur with high wind conditions. Higher wind speed may enhance long-range transport through rapid advection, howeever turbulent removal will also increase. These factors of maximum wind speed and precipitation frequency from April through early September will generally act to reduce the atmospheric lifetime of material being transported over the ocean, reducing effective source strength. Considering the countering influence of these two processes (transport and removal), the greatest potential for advection of continental material to Amsterdam Island should occur in the spring under conditions of relatively dry, high wind, stably stratified warm advection.

While seasonally varying large-scale meteorology can influence "effective" source strength, [Whelpdale and Moody, 1989] there is also seasonal variation in the "actual" source strength for all chemical constituents. A 

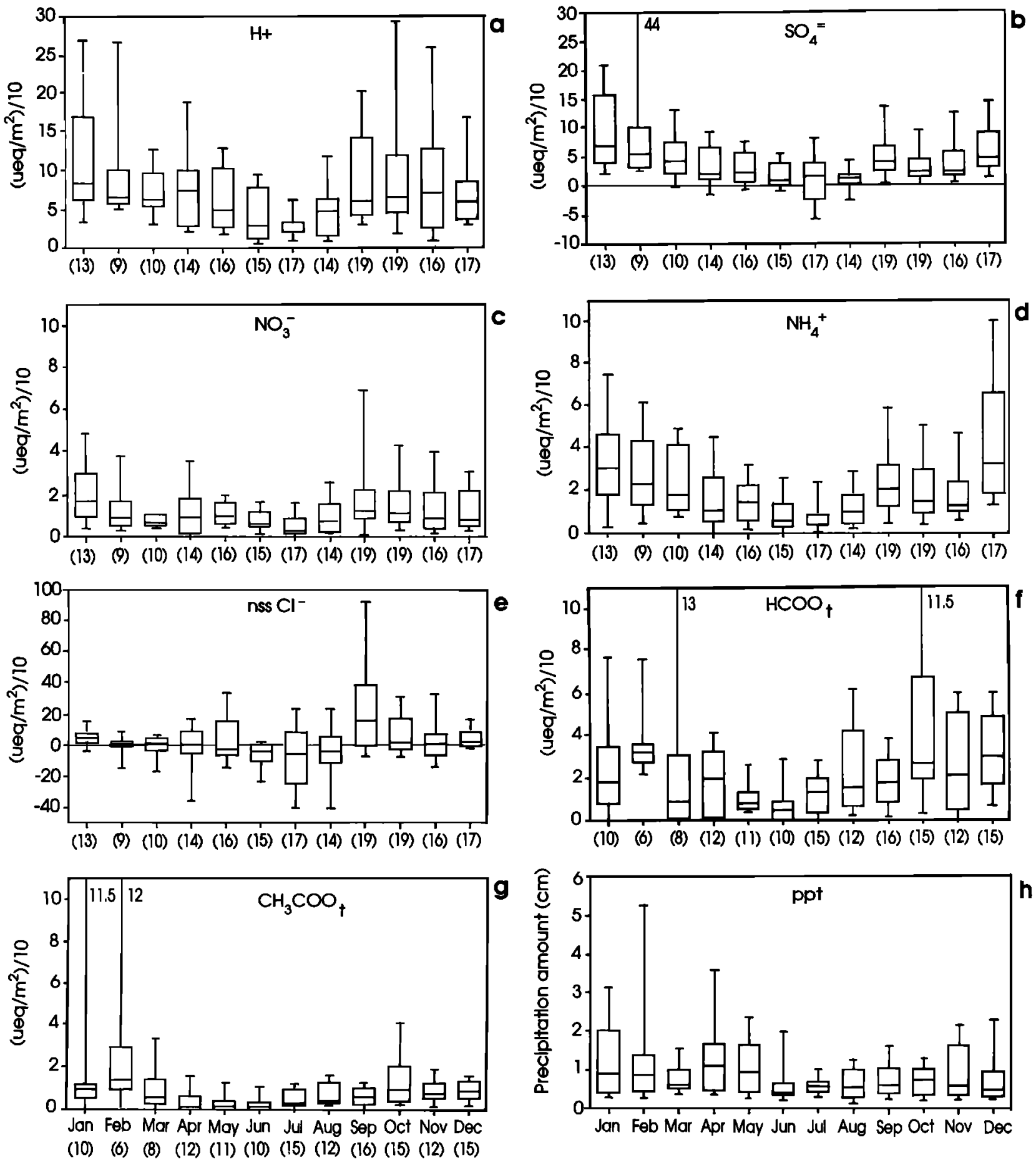

Fig. 3. Series of box plots summarizing monthly distributions of per event deposition for (a) $\mathbf{H}^{+}$, (b) nss $\mathrm{SO}_{4}{ }^{-}$, (c) $\mathrm{NO}_{3}^{-}$, (d) $\mathrm{NH}_{4}{ }^{+}$, (e) nss Cr, (f) $\mathrm{HCOO}_{\mathrm{t}}$, (g) $\mathrm{CH}_{3} \mathrm{COO}_{\text {, }}$, and (h) per event precipitation amount. Box

discussion of seasonality by chemical species is presented beginning with section 3.1.1. But first the contribution from local sources will be addressed.

There is a potential seasonal influence in local island sources. Fur seals uniformly distributed along the coast arrive in November and leave in January. Penguins inhabit the island from August through February, and

encloses 25 th to 75 th percentiles, 50 th percentile drawn inside, and upper and lower points are 90th and 10th percentiles, respectively. The number of events included in each month is listed in parentheses.

albatross arrive in September and leave at the end of March. These seabird rookeries are on the opposite side of the mountain from our sampling site (Figure 1). In an effort to assess the influence of these local sources on our precipitation data, ${ }^{22} \mathrm{Rn}$ has been used as a tracer for events with a strong local signal. Distributions of concentration and precipitation amount were statistically 


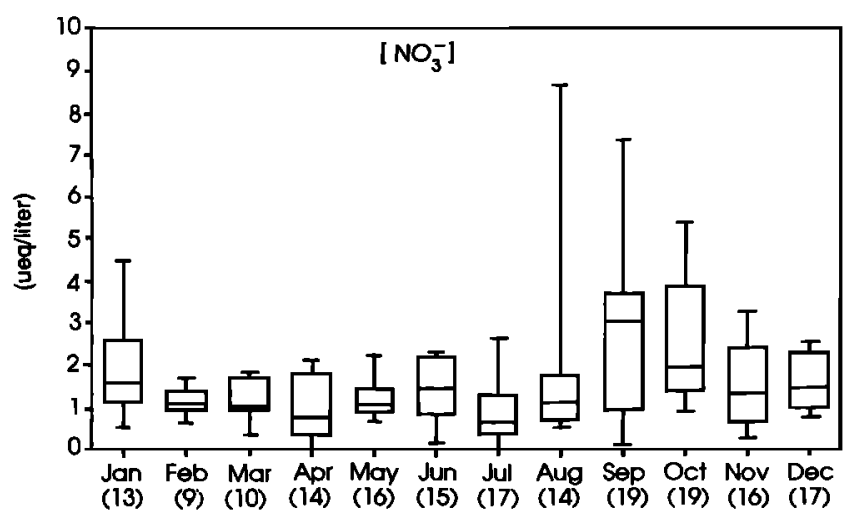

Fig. 4. Box plot of monthly distributions of $\mathrm{NO}_{3}^{-}$ concentration. Box encloses 25 th to 75 th percentiles, 50th percentile drawn inside, and upper and lower points are 90 th and 10th percentiles, respectively.

compared using the Kruskal-Wallis test for the radon categories "remote oceanic", "remote continental" and "local". Only the nss $\mathrm{K}^{+}$concentrations were enhanced in "local" events characterized by low winds and high ${ }^{222} \mathrm{Rn}$ of local origin. Aside from this difference, "local" events were not significantly different from "remote oceanic" events. "Remote continental" events had significantly higher $\mathrm{NO}_{3}{ }^{-}$and nss $\mathrm{SO}_{4}{ }^{-}$than local events (see section 3.4).

These results suggest that the contribution from local sources is primarily as wind-blown dust and plant material, potential sources for nss $\mathbf{K}^{+}$. Given the nature of the fauna, we might suspect a contribution of $\mathrm{NH}_{4}{ }^{+}$from locally generated $\mathrm{NH}_{3}$, but there is no systematic evidence of such contamination. On the basis of the lack of differences in chemistry for these comparisons, we conclude that the contribution from local sources is relatively unimportant.

3.1.1. nss $\mathrm{SO}_{4}{ }^{2}$. Constituents with a possible marine biogenic source, like nss $\mathrm{SO}_{4}{ }^{=}$, are influenced by a spring bloom in surface water productivity, which is correlated with greater insolation and higher sea surface temperatures [Nguyen et al., 1988]. Concentrations of nss $\mathrm{SO}_{4}{ }^{2}$ in precipitation on Amsterdam Island are correlated with an increased flux of biogenic emissions into the marine atmosphere [Nguyen et al., 1988]. The flux of locally generated dimethylsulfide (DMS) in the coastal waters off Amsterdam Island begins to increase in October, peaks in December at $4.4 \mu \mathrm{moles} / \mathrm{m}^{2} / \mathrm{d}$ and then drops to a minimum flux of $0.7 \mu \mathrm{mol} / \mathrm{m}^{2} / \mathrm{d}$ in August. This flux is directly correlated with the higher DMS concentration in the ocean surface water [Nguyen et al., 1990]. Using a more recent unpublished data set $[J . N$. Galloway and B.C. Nguyen, personal communication, 1990], this upward flux of DMS and the downward flux of $S$ deposition calculated from our precipitation data agree within a factor of 2 . Given all the uncertainties in flux calculations, this represents reasonably good aggreement. Temporal variations in the local DMS can account for about $60 \%$ of the seasonal variability in nss $\mathrm{SO}_{4}=$ deposition. This suggests that along with the process of local biogenic emission, other processes must contribute to the observed variability in nss $\mathrm{SO}_{4}{ }^{=}$.

In addition to dependence on biogenic precursors, a portion of nss $\mathrm{SO}_{4}{ }^{2}$ variability is related to seasonal variation in atmospheric reactivity. Transformation rates of reduced $\mathrm{S}$ species are a function of the atmospheric oxidant concentration. Hydroxyl radical concentrations in remote marine regions may fluctuate by a factor of 5 , with a maximum in the southern hemisphere summer and a minimum in winter [Crutzen, 1982]. This minimum in oxidant results from less insolation and lower temperatures during the cold season months and correspondingly less photochemical activity.

On Amsterdam Island, nss $\mathrm{SO}_{4}{ }^{2}$ deposition goes up in September along with oxidant concentrations, which may increase dramatically with the transport of ozone plumes from biomass burning in Africa. This is discussed further in section 3.1.4. It suggests that along with local biogenic emissions, remote $S$ sources enhanced by favorable transport and transformation conditions contribute to the springtime maximum in observed $\mathrm{nss} \mathrm{SO}_{4}{ }^{2}$.

3.1.2. $\mathrm{NH}_{4}^{+}$. The monthly VWA concentrations of $\mathrm{NH}_{4}{ }^{+}$show a minimum in May-August and a maximum in September through December (Figure 2). This pattern is similar to that of nss $\mathrm{SO}_{4}{ }^{=}$with the exception of the January-March period. This exception disappears when percentile distributions of per event deposition are plotted by month (Figure 3d). The deposition of $\mathrm{NH}_{4}{ }^{+}$like that of nss $\mathrm{SO}_{4}{ }^{2}$ appears to be seasonally dependent. The processes influencing the nss $\mathrm{SO}_{4}=$ variability were discussed above. For $\mathrm{NH}_{4}^{+}$the seasonal dependency on per event deposition is most likely due to a seasonally variable source strength. One possibility, as noted earlier, is the impact of the local seabird/seal populations that vary on a monthly basis (section 3.1). However, there is no evidence of significant local contamination from these sources. The second explanation is that ammonia is emitted from the sea surface as a result of biological processes. Quinn et al. [1990] have shown that the Pacific Ocean provides a biogenic source for ammonia with an emission rate of $98 \pm 78 \mathrm{~g} \mathrm{~N} / \mathrm{m}^{2} / \mathrm{d}$. Averaged over the year, this flux is $0.036 \pm 0.028 \mathrm{~g} \mathrm{~N} / \mathrm{m}^{2} / \mathrm{y}$. The wet deposition rate of $\mathrm{NH}_{4}^{+}$from the data discussed in this paper is $0.038 \mathrm{~g} \mathrm{~N} / \mathrm{m}^{2} / \mathrm{y}$. There are obvious dangers in extrapolating a short-term flux for the Pacific Ocean to an annual flux for the central southern Indian Ocean. However, on the basis of this comparison, it does appear that the oceanic emission of $\mathrm{NH}_{3}$ could account for the observed deposition of $\mathrm{NH}_{4}{ }^{+}$. A biogenic source peaking with a spring bloom in surface water productivity would be consistent with our observations.

3.1.3. Carboxylic Acids. The seasonal variations in per event depositions for $\mathrm{HCOO}_{\mathrm{t}}$ (Figure 3f) and $\mathrm{CH}_{3} \mathrm{COO}_{4}$ (Figure 3g) presented here are similar to those previously discussed by Keene and Galloway [1988] for a data subset corresponding to the period from September 1981 to June 1986. Median depositions for both species 
were generally lowest during the winter months of May through July and were highest during the spring and summer months of October through February. The seasonal cycle is not identical for each, however, as median depositions of $\mathrm{HCOO}_{\text {, remained relatively high }}$ during the autumn (March and April), whereas median depositions of $\mathrm{CH}_{3} \mathrm{COO}_{2}$ decreased through that period. These distinctions in the seasonal cycles suggest the two species originate from different precursor compounds.

Keene and Galloway [1988] and Galloway et al. [1989] have pointed out that maximum and extreme per event depositions of carboxylic acids in marine regions tend to peak during periods when phytoplankton blooms are expected. Such a cycle is consistent with the hypothesis of a marine biogenic source for precursor hydrocarbons as suggested by $G$. R. Harvey and $R$. $F$. Lang [personal communication, 1990]. The observed seasonalities in deposition (Figures $3 f$ and $3 g$ ) for carboxylic species at Amsterdam Island support such a hypothesis.

3.1.4. $\mathrm{NO}_{3}{ }^{-}$. The seasonal variation in $\mathrm{NO}_{3}{ }^{-}$is different from the other ions in that high concentrations are confined primarily to the early austral spring months of September and October. We expect all of the $\mathrm{NO}_{3}{ }^{-}$to be associated with long-range transport, because it has no known oceanic or significant local sources. The timing of these high $\mathrm{NO}_{3}^{-}$values corresponds to the peak production period for tropospheric ozone resulting from widespread biomass burning on the African continent [Fishman et al., 1990]. The burning occurs between August and October, and plots of satellite-derived tropospheric ozone indicate that peak concentrations are observed between September and November. A significant amount of biomass burning also occurs on the island of Madagascar during this time.

Plumes of high $\mathrm{O}_{3}$ concentration were observed by Fishman et al. [1990] in satellite data off the western African coast over the South Atlantic Ocean between the equator and $20^{\circ}$ south. A band of high $\mathrm{O}_{3}$ concentration was also observed between $25^{\circ}$ and $40^{\circ}$ south over the southern Indian Ocean. J. Fishman Ipersonal communication, 1989] suggests this may be material advected westward off Africa in the low latitude easterlies, eventually advected poleward and incorporated in the westerlies at higher latitudes. This mechanism, as well as more direct north-westerly flow from the southern tip of Africa and Madagascar, potentially provides Amsterdam Island with a spring anthropogenic continental source. This correspondence between $\mathrm{O}_{3}$ and $\mathrm{NO}_{3}{ }^{-}$suggests that the time dependence of $\mathrm{NO}_{3}^{-}$concentrations in particular could be a function of a time-dependent biomass-burning source coupled with efficient transport.

Using results from a general circulation model to investigate the global N budget, Levy and Mox im [1989] found that anthropogenic emissions of $\mathrm{N}$ from fossil fuel combustion sources could not account for the observed levels of $\mathrm{NO}_{\mathrm{y}}$ in the precipitation of the southern hemisphere. They proposed three possible sources for the additional nitrogen: 1) transport from biomass burning (probably as PAN), 2) injection from the stratosphere [Levy, et al. 1980], and 3) an unknown local or oceanic source. While stratospheric injection is generally the primary source of $\mathrm{O}_{3}$ at higher latitudes [Fishman et al., 1990], the work of Legrand and Delmas [1986] found no evidence of a stratospheric source for $\mathrm{NO}_{3}{ }^{-}$at a site in Antarctica.

A significant problem in modeling wet deposition using a general circulation model arises from the difficulty of parameterizing the influence of brief episodic occurrences of long-range transport using average meteorology. A case in point is the extreme event which occurred October 5,1985 . It made a significant contribution to total $\mathrm{NO}_{3}^{-}$ deposition and indicates the potential importance of episodic long-range transport of anthropogenic emissions.

The VWA $\mathrm{NO}_{3}^{-}$concentration for October is strongly influenced by this extreme event occurring with a concentration of $38.1 \mu \mathrm{eq} / \ell$ of nitrate. This is comparable to a polluted precipitation event at a continental U.S. site like Rockport, Indiana [Moody and Samson, 1989]. This episode resulted in extremely high concentrations for all constituents and was associated with a relatively large $(0.97 \mathrm{~cm})$ precipitation amount.

Precipitation for this particular event began in the early morning before $0500 \mathrm{LT}$, and continued as a drizzle and light rain for 5 hours. Trajectories arriving at Amsterdam Island at 0500 on October 5, and at 1700 LT the previous day indicated a well-defined flow pattern persisted, characterized by rapid transport at the $\mathbf{8 5 0}$ mbar level for air parcels leaving the eastern African coast 3 days earlier. This represents sustained wind speeds of roughly $70 \mathrm{~km} / \mathrm{h}$. Additionally, both trajectories indicate 2 or 3 days of stagnation over the eastern south African coast, around $25^{\circ}$ south latitude prior to the rapid offshore flow. This region is potentially influenced by large anthropogenic emissions in the Eastern Transvaal Highveld [Ty son et al., 1988]. While this event was not classified as remote continental by its radon level, a radon concentration peak of $4 \mathrm{pCi} / \mathrm{m}^{3}$ occurred approximately 12 hours before precipitation began, suggesting the arrival of a continental air mass over Amsterdam Island. A temporal analysis of temperature, pressure, wind and moisture variables indicates rapid warm moist flow from the west-northwest characterized by elevated ${ }^{222}$ Rn concentrations indicative of continental air (Figure 5). This was followed by an abrupt change during the early morning of October 5, indicative of a classic frontal passage. These factors suggest that this is a "good" measurement, representing an extreme episode. The corresponding information of transport and radon further establishes the credibility of the data, strongly suggesting an influx of polluted air from the southern African continent.

While this single event has a very large influence on the VWAs for October, it is important to note that the pattern of higher $\mathrm{NO}_{3}{ }^{-}$in the austral spring is still observed even when this event is ignored. Two thirds of all the $\mathrm{NO}_{3}^{-}$ concentrations greater than $2.5 \mu \mathrm{eq} / \ell$ were associated 

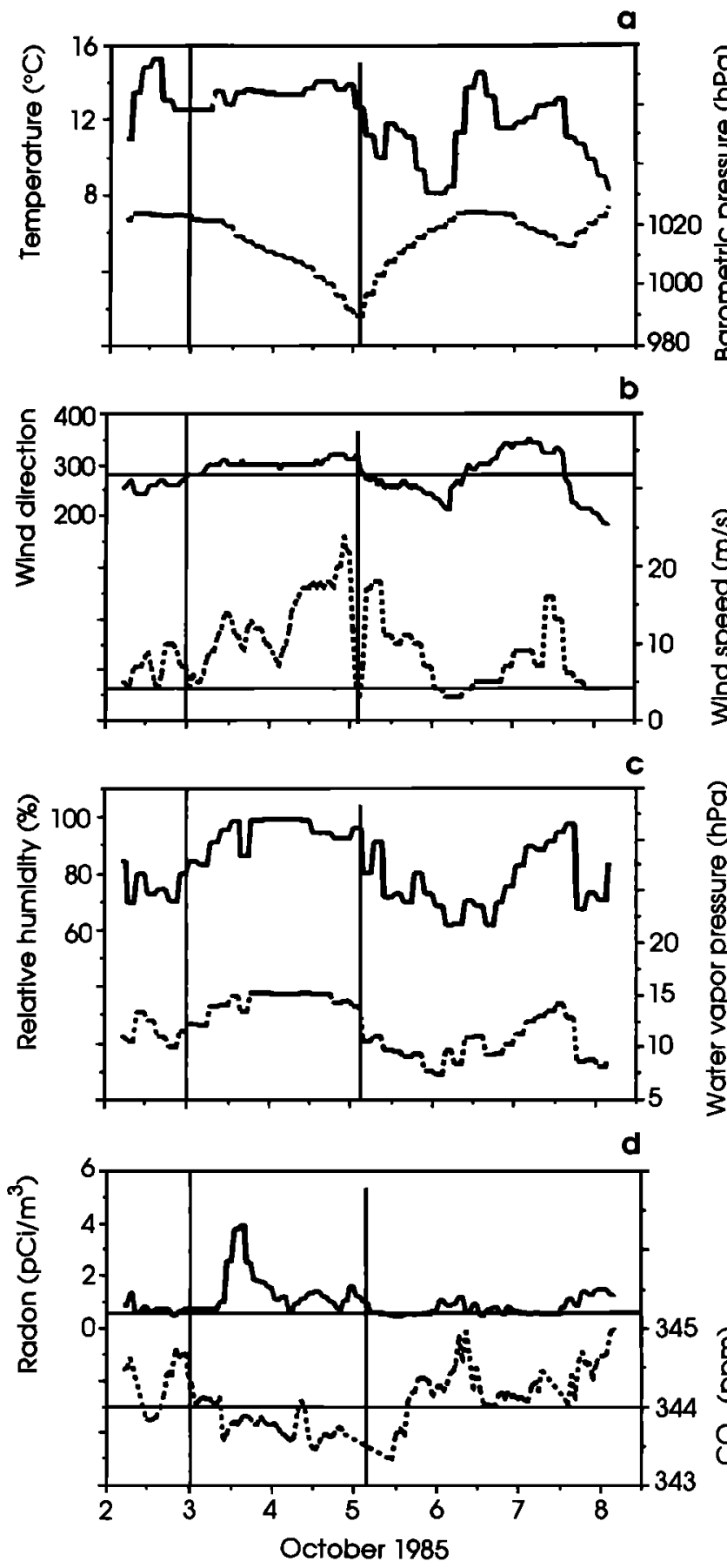

Fig. 5. Time variation of temperature, pressure, wind speed and direction, relative humidity, water vapor pressure, radon, and $\mathrm{CO}_{2}$ corresponding to extreme chemical deposition event on October 5, 1985. Depiciting flow of warm moist air, rich in radon arriving from the west northwest (300\%), followed by abrupt change early on October 5 , indicative of cold frontal passage.

with precipitation sampled in the months August through November.

Chemically, such an extreme event has important implications in terms of understanding and modeling the average composition of the marine atmosphere. For example, given all events collected between 1980 and 1987, this single sample accounts for more than $13 \%$ of the $\mathrm{NO}_{3}{ }^{-}$ deposition and roughly $5 \%$ of the nss $\mathrm{SO}_{4}{ }^{=}$, carboxylic acid, $\mathrm{NH}_{4}^{+}$, and $\mathrm{H}^{+}$deposition. Recognizing that we have sampled only $25 \%$ of the events over this time period suggests that the contribution from episodic long-range transport could be substantial. As of January 1991 we began sampling all precipitation events on Amsterdam Island, this will allow for a future assessment of the frequency of occurrence of these extreme episodes.

3.1.5. nss $\mathrm{Cl}^{-}$. Direct injection of sea-salt aerosol from the ocean surface is by far the major source for atmospheric chlorine over the southern Indian Ocean [Keene et al., 1986]. Volitalization of $\mathrm{Cl}$ from sea-salt aerosol has long been recognized as the principal source for vapor phase $\mathrm{Cl}$ in the marine troposphere (e.g., Cicerone, 1981]. Many investigators have suggested that $\mathrm{HCl}$ is released directly from sea-salt aerosol that has been acidified to low $\mathrm{pH}$ by the addition of strong mineral acids, but recently this hypothesis has been questioned, and an alternative mechanism involving $\mathrm{O}_{3}$ reactions at sea-salt aerosol surfaces has been proposed [Keene et al., 1990 ]. Assuming that virtually all $\mathrm{Cr}$ measured in precipitation at Amsterdam Island originates with sea-salt aerosol and that a mechanism exists to release vaporphase $\mathrm{Cl}$ from this aerosol, then different atmospheric lifetimes for the particulate and vapor phase species could explain the variability in the amount of nss $\mathrm{Cr}$ in precipitation. Whether released directly or produced photochemically from a released precursor, it is likely that $\mathrm{HCl}$ is the principal $\mathrm{Cl}$ gas in the marine troposphere. If $\mathrm{HCl}$ has a longer atmospheric lifetime relative to particulate $\mathrm{Cr}$, and if both phases are scavenged with equal efficiency by precipitation, then positive nss $\mathrm{Cr}$ will exist in precipitation. Such a mechanism would result in a contribution from $\mathrm{HCl}$ to the free acidity of marine precipitation.

The nature of the desorption mechanism for $\mathrm{Cl}$ gas is an important consideration in assessing the ultimate source of the acidity contributed to precipitation by $\mathrm{HCl}$. If $\mathrm{HCl}$ is released from sea-salt aerosol by acid displacement reactions, the acidity from $\mathrm{HCl}$ ultimately originates with $\mathrm{H}_{2} \mathrm{SO}_{4}$ and $\mathrm{HNO}_{3}$. However, if $\mathrm{HCl}$ is produced from reactions involving $\mathrm{Cl}_{2}$ that is released from sea-salt aerosol as suggested by Keene et al. [1990], then the acidity contributed by $\mathrm{HCl}$ may arise from a photochemical mechanism as follows:

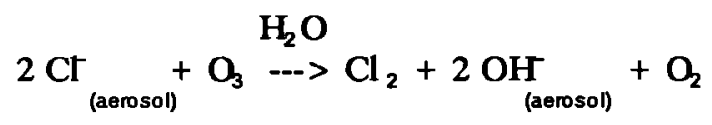

Photolysis of $\mathrm{Cr}$ during the daytimes takes place on a time scale of minutes to produce $\mathrm{Cl}$ atoms which react rapidly to yield $\mathrm{HCl}$.

A distinct seasonal pattern is evident in the median nss $\mathrm{Cr}$ data (Figure $3 \mathrm{e}$ ) with slightly negative median per event depositions during late autumn and winter months (May through August), a sharp peak in September, and slightly positive values the remainder of the year. When the data are aggregated by season as in Table 3 , the mean 
deposition of nss $\mathrm{Cr}$ is positive in both seasons. However, the mean and median describe different aspects of these skewed distributions, and it does appear that there are months with significant nss $\mathrm{Cr}$ concentration deficits.

Negative median depositions during winter months may be related to two factors. If $\mathrm{HCl}$ has a shorter atmospieric lifetime than particulate $\mathrm{Cr}$ during the winter (e.g., Kritz and Rancher, 1980], then $\mathrm{Cr}$ deficits, which are typically observed in sea-salt aerosol, would be reflected in marine precipitetion.

Another possibility is that the sea-salt componer: may be slightly overestimated by using $\mathrm{Na}^{+}$as a reference species. While a regression analysis found no significant differences in the ratio of $\mathrm{Na}^{+}: \mathrm{Mg}^{++}$relative to seawater, the average per event concentration and deposition for $\mathbf{M g}^{++}$during the winter was negative (Table 3) suggesting small but finite nss concentrations of $\mathrm{Na}^{+}$in the samples. If we assumed that $\mathrm{Mg}^{++}$were a conservative tracer of scasalt, the winter mean per event deposition suggests that nss $\mathrm{Cr}$ may be underestimated by approximately $10, \mathrm{eq} / \mathrm{m}^{2}$ on average. This average underestimate would vary seasonally and is within the range of median $\mathrm{Cl}$ deficits observed from May through August.

The peak in positive median and extreme nss $\mathrm{Cl}^{-}$observed in September (Figure 3e) occurs in conjinction with a peak in median and extreme depositions of $\mathrm{NO}_{3}{ }^{-}$ (Figure 3c). These high depositions of $\mathrm{NO}_{3}{ }^{-}$and nss $\mathrm{Cr}$ appear to be associated with the long-range atmospheric transport of combustion products from biomass burning or industrial sources in Africa, as discussed above. Keene et al. [ 1990 ] found that combustion products were associated with enhanced volatilization of $\mathrm{Cl}$ trom sea-salt aerosol and elevated concentrations of $\mathrm{HCl}$ in the North Atlantic boundary layer. If $\mathrm{HCl}$ has a longer atmospheric lifetime than sea-salt aersol, such conditions may contribute to significant concentrations of $\mathrm{HCl}$ in precipitation. It appears that continental emissions may at times influence the chemical cycling of reactive $\mathrm{Cl}$ through the marine troposphere even at extremely remote locations such as Amsterdam Island. The mechanisms involved and their implications for marine photochemistry are the focus of on-going research.

3.1.6. $H^{+}$. The $\mathrm{pH}$ of precipitation on Amsterdam Island is weakly acidic, ranging from a VWA of 5.2 in June to 4.8 in October, with extreme values as low as 4.2. Seasonal patterns in $\mathrm{H}^{+}$deposition and concentration are similar to those of nss $\mathrm{SO}_{4}{ }^{-}$, with the lowest and least variable per event depositions and concentrations occurring in June and July.

The acidity of precipitation on Amsterdam Island results from the mix of acids $\left(\mathrm{H}_{2} \mathrm{SO}_{4}, \mathrm{HNO}_{3}, \mathrm{HCl}, \mathrm{HCOOH}\right.$, and $\left.\mathrm{CH}_{3} \mathrm{COOH}\right)$ and bases $\left(\mathrm{NH}_{3}, \mathrm{CaCO}_{3}\right.$, and $\left.\mathrm{NaCO}_{3}\right)$ scavenged by precipitation. To estimate the maximum potential contribution of each acid to the original free acidity, the ratio of each anion concentration to the original acidity was determined. Original acidity was approximated as the $\mathrm{H}^{+}$concentration plus the

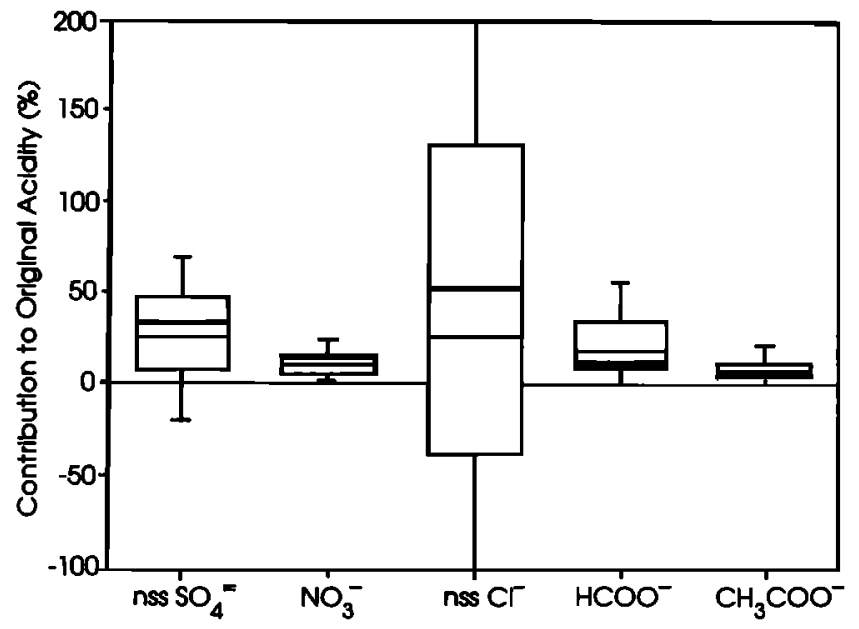

Fig. 6. Potential contribution of the anions nss $\mathrm{SO}_{4}{ }^{2}$, $\mathrm{NO}_{3}^{-}$, nss $\mathrm{Cr}$, and the organics ( $\mathrm{HCOO}$ and $\mathrm{CH}_{3} \mathrm{COO}$ ) to precipitation acidity.

concentrations of sea-salt alkalinity, nss $\mathrm{Ca}^{++}$, and $\mathrm{NH}_{4}^{+}$. Distributions of this ratio are presented in Figure 6. The ratio of the VWA anion concentration to the VWA orginial acidity is also plotted for each species.

Considering all the data together, nss $\mathrm{SO}_{4}{ }^{2}$, nss $\mathrm{Cr}$, and the organics each have the potential to contribute about $25 \%$ of the $\mathrm{H}^{+}$on average (median), with $\mathrm{NO}_{3}^{-}$contributing about $12 \%$. Uncertainties in the calculated values of nss $\mathrm{SO}_{4}{ }^{\circ}$ and nss $\mathrm{Cr}$ make it difficult to provide a more quantitative analysis of contributions to acidity. For example the unequal variances mask any strong linear relationship between either of these anions and $\mathrm{H}^{+}$, violating the assumptions required for a multiple linear regression. A further complication is the presence of negative calculated values which prohibit transforming the data to a logarithmic scale for analysis. However, this qualitative assessment does suggest that no single acid dominates. It illustrates the relative importance of the carboxylic acids in the remote marine environment and demonstrates there is the potential for $\mathrm{HCl}$ to make a significant contribution to precipitation acidity.

\subsection{Interannual Variability}

Along with variations in precipitation composition within the year, there are also variations between years. Some of this variability can be related to interannual differences in large-scale circulation patterns. Plots of the VWA concentrations of $\mathrm{H}^{+}$, nss $\mathrm{SO}_{4}{ }^{2}$, and $\mathrm{NO}_{3}{ }^{-}$from 1980 through 1986 indicate considerable variation from year to year (Figure 7). Since we are interested in relating interannual differences to atmospheric dynamics, the annual cycle used runs from May through the following April. This is the cycle which best describes the Southern Oscillation Index, referred to below.

The most variable constituent is nss $\mathrm{SO}_{4}{ }^{2}$; from 1980 to 1982 the average concentration decreased by almost a factor of 5. Figure 8 is a plot of the nss $\mathrm{SO}_{4}{ }^{*}$ 


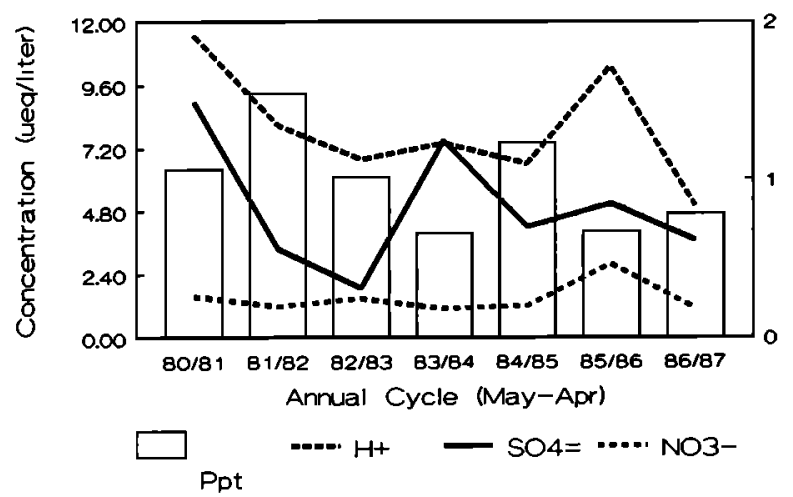

Fig. 7. Volume weighted average concentrations of $\mathbf{H}^{+}$, nss $\mathrm{SO}_{4}{ }^{-}$, and $\mathrm{NO}_{3}{ }^{-}$by annual cycle (May-April) using data from May 1980 to January 1987. The number of events in each annual cycle follows: $1980 / 1981 \mathrm{n}=25 ; 1981 / 1982$ $\mathrm{n}=24 ; 1982 / 1983 \mathrm{n}=21 ; 1983 / 1984 \mathrm{n}=15 ; 1984 / 1985$ $n=13 ; 1985 / 1986 n=53 ; 1986 / 1987$ (through January 1987 ) $\mathrm{n}=28$.

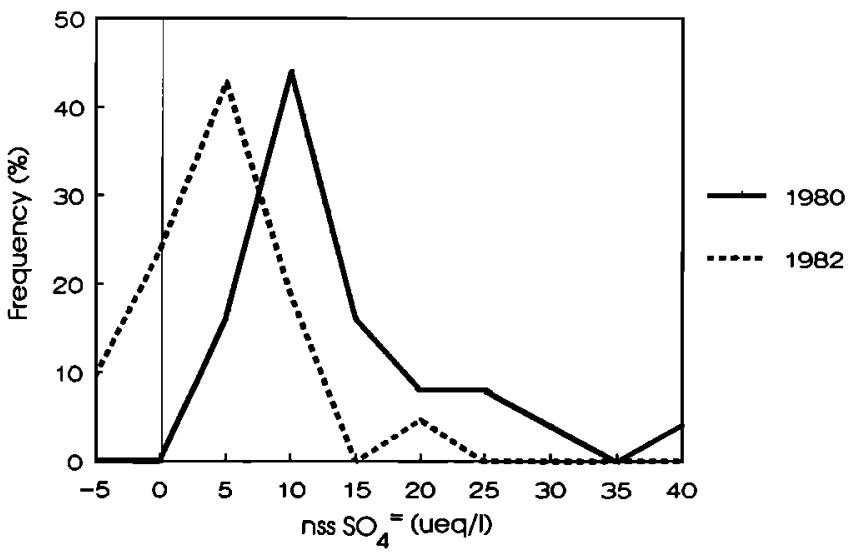

Fig. 8. Concentration profiles for nss $\mathrm{SO}_{4}{ }^{2}$ by year for the two annual cycles May 1980 to April $1981(n=25)$ and May 1982 to April $1983(n=21)$, strong and weak years, respectively, of the Southern Oscillation.

concentration profiles for these annual cycles which better illustrates this difference. This drop in nss $\mathrm{SO}_{4}{ }^{2}$ concentration does correspond to an increase in the precipitation volume per storm which will enhance dilution, however, there appears to be an additional factor influencing the composition.

There is an obvious difference in transport patterns associated with precipitation events for the two years 1980 and 1982, with a notable lack of flow from southern Africa and Madagascar during 1982 (Figure 9). Our trajectory analysis is consistent with a flow climatology for Amsterdam Island which indicates that trajectories arrived from the African continent or Madagascar $22 \%$ of the time in 1980 , while the frequency dropped to $13 \%$ of the time in 1982 [J.M. Miller, personal communication, 1990]. The average per event depositions of $\mathrm{SO}_{4}{ }^{2}, \mathrm{H}^{+}$, and $\mathrm{NO}_{3}^{-}$are also noted on Figure 9. Even though events in 1982 occurred with more precipitation per event, the
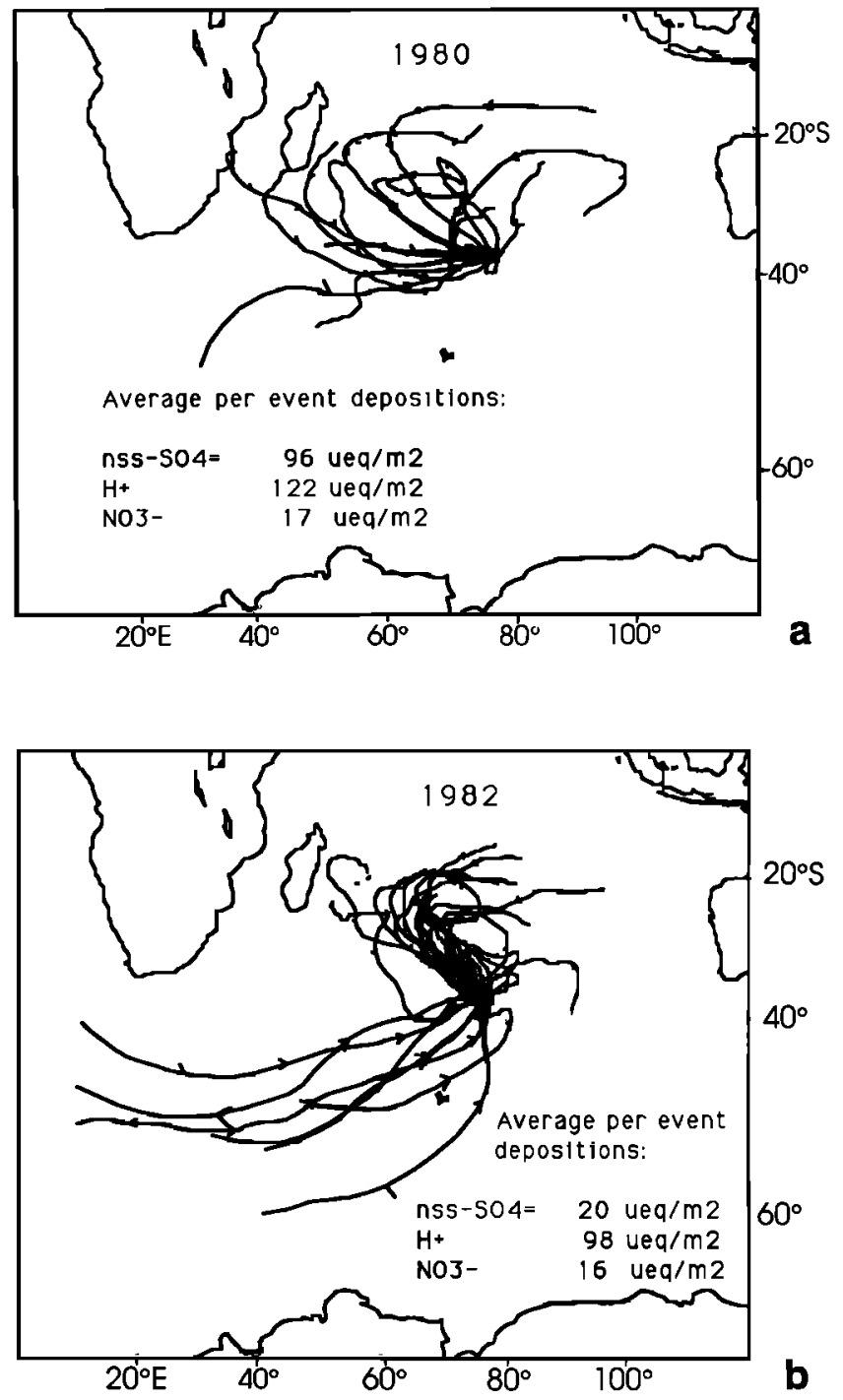

Fig. 9. Transport patterns at $850 \mathrm{mbar}$ for air masses arriving on Amsterdam Island during precipitation events for the two years 1980 and 1982. Average per event depositions are noted for each period.

per event deposition of nss $\mathrm{SO}_{4}{ }^{*}$ was significantly greater in 1980 when trajectories suggest more transport from the north and west. Interannual differences in the distributions of per event deposition of $\mathrm{H}^{+}$and $\mathrm{NO}_{3}{ }^{-}$were not statistically significant. This suggests that this region has more influence as a source of $S$ than as a source for $\mathrm{N}$, potentially implicating a biogenic oceanic source rather than a continental anthropogenic source.

It is important to note that the years 1980 and 1982 are defined as strong and weak years, respectively, of the Southern Oscillation [Meehl, 1987]. The Southern Oscillation is defined as the exchange of atmospheric mass between the Indian and Pacific oceans [Walker and Bliss, 1930; Philander, 1990] and it is linked to variations in sea surface temperature observed in the tropical Pacific giving rise to the terms El Nino-Southern Oscillation events, or warm events. The year 1982 was such a warm event, with a strong El Nino. 
One of the well-known indicators of a strong annual cycle of the Southern Oscillation is the strength of the Indian monsoon. The average summer monsoon rainfall over India was $10 \%$ above normal in 1980 and over $10 \%$ below normal in 1982 [Rasmussen and Arkin, 1990]. During strong years, like 1980, sea surface temperatures SE of Madagascar are higher than the previous year from October through April, between roughly $25^{\circ}$ and $35^{\circ}$ south, and $40^{\circ}$ to $65^{\circ}$ east [Meehl, 1987]. In addition, the Indian circumpolar trough is weakened, and the subtropical band of high pressure is strengthened.

Conversely, in a weak year like 1982 (a strong El Nino year, Rasmusson and Wallace, 1983], the southern hemisphere subtropical high weakens, and there appears to be a significant decrease in transport from the northwest arriving at Amsterdam Island. The influence of this El Nino year was detected at another GPCP site, Katherine, Australia [Likens et al., 1987], by below normal precipitation in the wet season and relatively high concentrations influenced primarily by low precipitation amount.

These results indicate that interannual differences in precipitation composition may be influenced by interannual differences in large-scale circulation which cause year-to-year differences in transport and a time-varying contribution from specific source "regions". Furthermore, we might also expect to see nss $\mathrm{SO}_{4}{ }^{2}$ concentrations influenced by an interannual difference in source strength if there is a link between higher sea surface temperatures and increased marine emissions of DMS through either increased productivity, a change in phytoplankton speciation, or a change in surface wind speed [Charlson et al., 1987]. The importance of these large-scale climate variations on precipitation composition is the subject of continuing research.

\subsection{Variability Within Seasons: Transport Clusters}

The technique of cluster analysis was used to identify variability within a season related to day-to-day variations in meteorology. Given the temporal pattern of chemical variation described earlier, the cluster analysis was performed for two periods in an effort to reduce the confounding influence of seasonal variability in chemistry. The cluster analysis identified four transport patterns each in the cold season (April-September) and in the warm season (October-March), respectively. Upon plotting the results it was noted that unclustered trajectories in each season (excluded because they terminated less than five days back from Amsterdam Island) formed relatively well-defined patterns of generally high wind speeds from the west southwest. This cluster was retained in each season as a valid transport pattern, and its composition has been considered in these analyses.

A distinct seasonal variation in general flow is evident in the 850 mbar trajectories with transport from the west and west/southwest more frequent during the southern hemisphere winter (Figure 10). Flow from the north is more prevalent during the summer (Figure 11). These

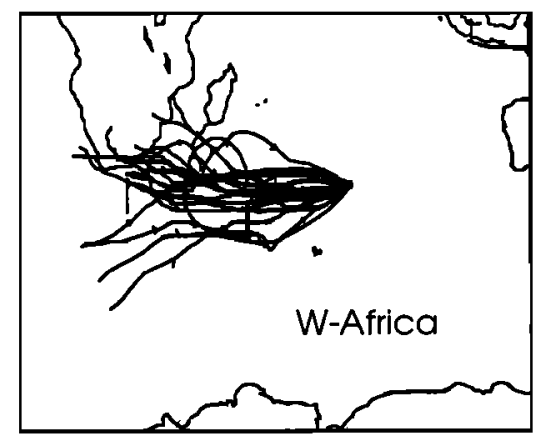

April-September 1980-1986

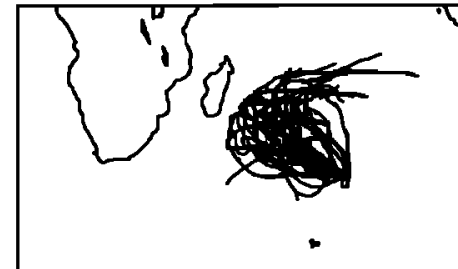

NW-Madagascar

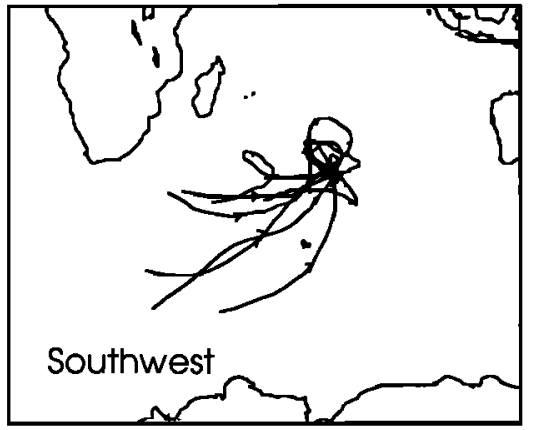

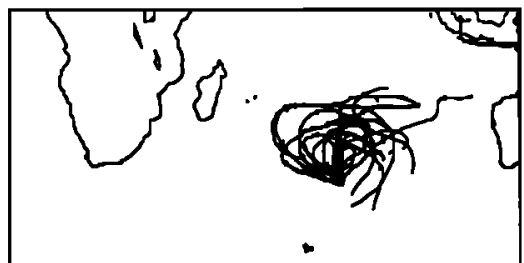

North \& East
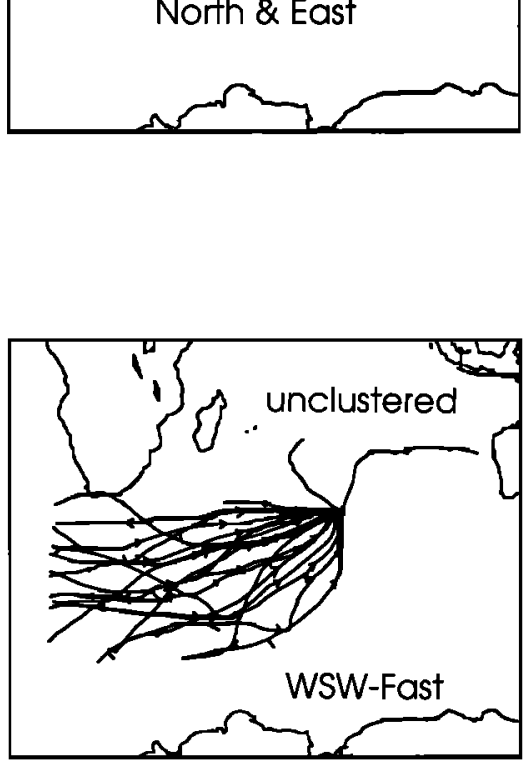

Fig. 10. Five winter transport patterns defined by cluster pattern provide qualitative reference of general source analysis of $\mathbf{8 5 0} \mathrm{mbar}$ trajectory data. Labels for each region. 

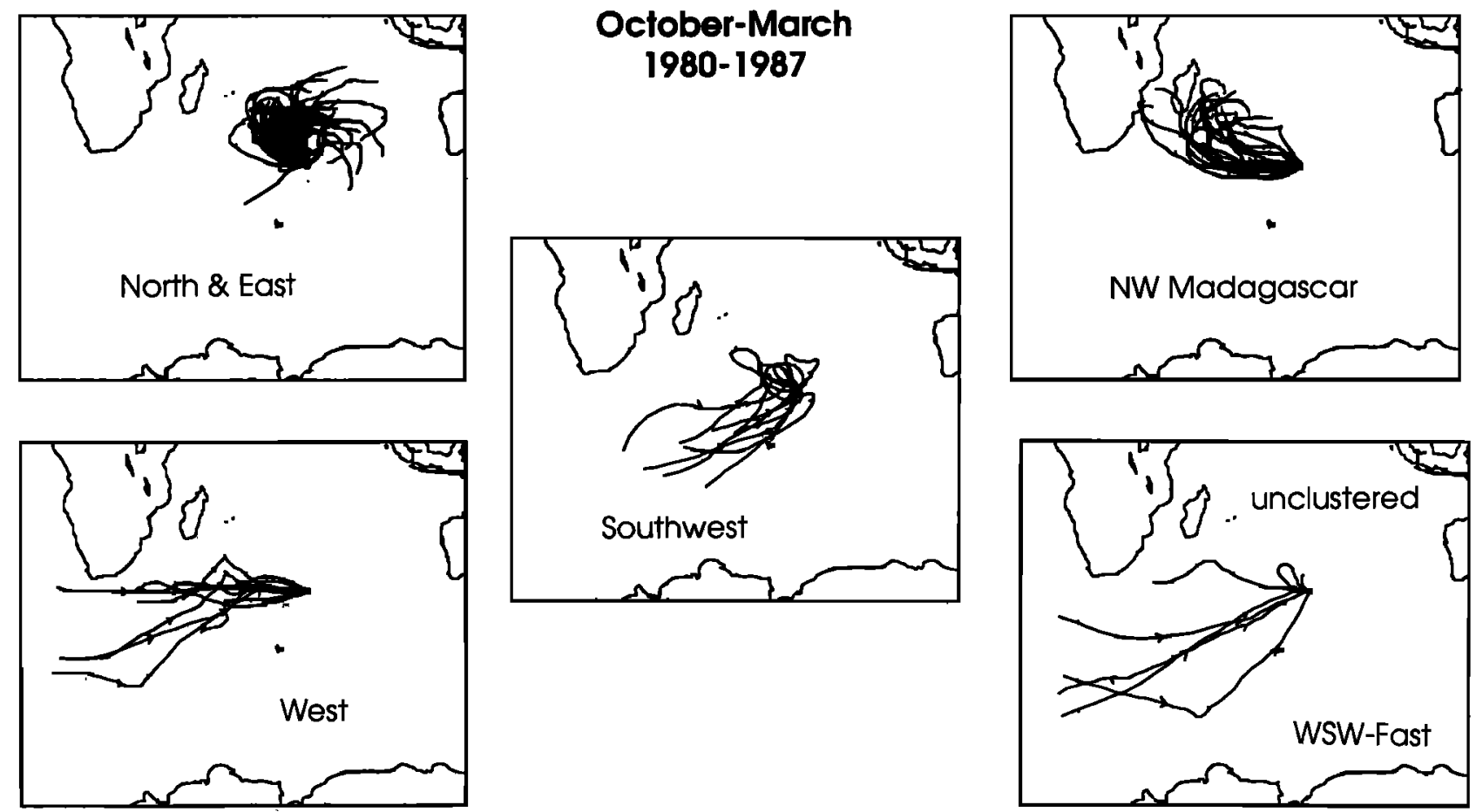

Fig. 11. Five summer transport patterns defined by each pattern provide qualitative reference of general cluster analysis of $\mathbf{8 5 0}$ mbar trajectory data. Labels for source region.
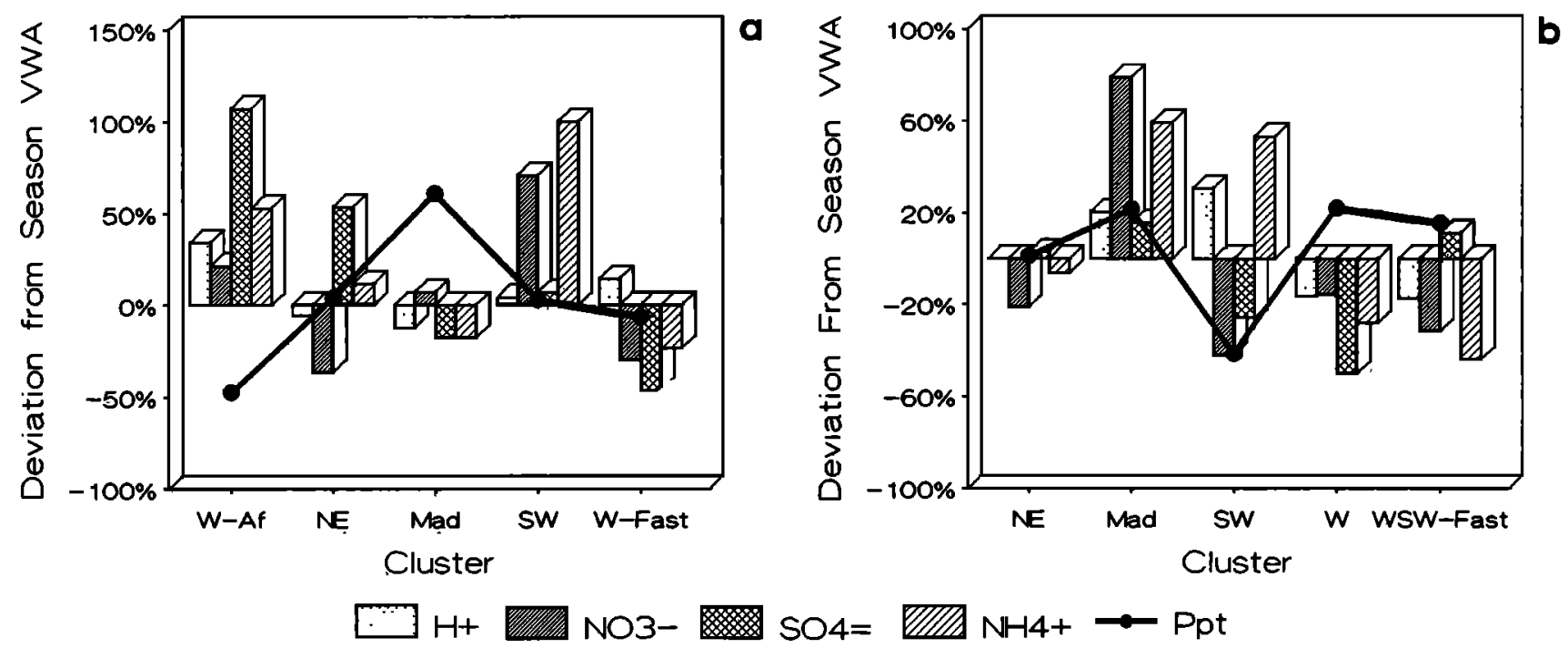

Fig. 12. Relative concentration factors, defined as the (April-September), and (b) Southern Hemisphere summer deviation of the VWA per cluster from the VWA for the (October-March), respectively.

entire season, for (a) South Hemisphere winter

differences correspond with seasonal variation in the strength and location of the subtropical high [Taalj ard and Van Loon, 1984].

Relative concentration factors, defined as the deviation of the VWA per cluster from the VWA for the entire season [Moody and Galloway, 1988], are shown for the cold season clusters in Figure 12a. Transport from the west (Africa), generated events with above average concentration, although the per event precipitation amount was $50 \%$ below average. In contrast, the per event precipitation amount was $50 \%$ above average in transport from Madagascar, and the concentrations were generally below the seasonal average. These results suggest that differences in cold season chemistry are largely influenced by differences in precipitation amount. To assess the influence of storm size, comparisons of per event deposition were made.

Significant differences in per event deposition were identified between cold season transport patterns using the nonparametric Kruskal-Wallis test [Conover, 1980]. In 
spite of higher concentrations, events associated with transport from the west (Africa) and the W-East deposited less material per event relative to the other transport patterns. Per event nss $\mathrm{SO}_{4}{ }^{2}$ deposition was highest in transport from the $\mathrm{N}$ and $\mathrm{E}$.

Similarly, distributions of per event concentration were statistically compared between clusters and the only constituent with a significant difference related to cold season transport was $\mathrm{Na}^{+}$. $\mathrm{Na}^{+}$was most concentrated in flow from Africa, with low precipitation amount and high wind speeds, and least concentrated in flow from the $\mathbf{N}$ and $E$, with relatively low wind speeds.

In the warm season (Figure 12b) the highest VWA concentrations were associated with transport from Madagascar and occurred with relatively high precipitation amounts. Low VWA concentrations of nss $\mathrm{SO}_{4}{ }^{=}$and $\mathrm{NO}_{3}^{-}$ from the SW occurred with low volume events. These results suggest precipitation volume has less influence on chemical composition than was noted for the cold season. Using a statistical comparison of distributions of per event concentrations and per event depositions, only $\mathrm{NO}_{3}^{-}$ deposition varied significantly with warm season transport, with highest deposition occurring with transport from Madagascar. The lack of significance in the nonparametric distributional tests for many species suggests that chemical differences based on transport are not large.

Figure 13 illustrates the percent of the 8-year total deposition associated with each transport pattern by season. Overall, transport from Madagascar and the NE delivers the largest fraction of precipitation and chemical deposition. Over $40 \%$ of the nss $\mathrm{SO}_{4}{ }^{2}$ and $\mathrm{NO}_{3}{ }^{-}$deposited on Amsterdam Island during the period of record was associated with this flow pattern.

It is not surprising that transport alone does not explain much of the variability in precipitation chemistry at the site. Defining transport patterns only on the basis of isobaric wind speed and direction ignores other important factors like the variable influence of upwind removal by

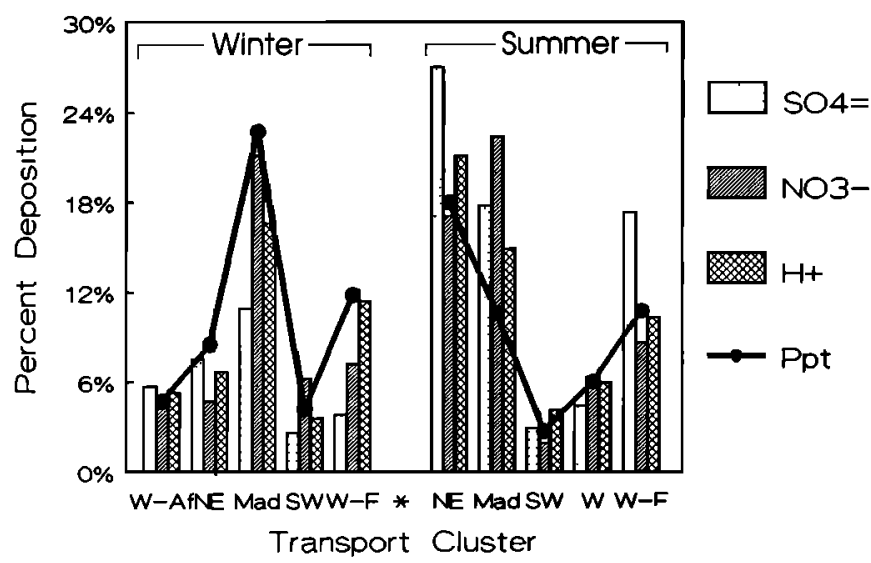

Fig. 13. Percent of total deposition delivered to Amsterdam Island between May 1980 and January 1987 by transport clusters defined for the winter and summer seasons, respectively. precipitation enroute to Amsterdam Island, venting through cumulus convection, transformation rates related to both gas- and aqueous-phase chemistry, and other smaller-scale variations.

Similar transport patterns occur in both seasons. Given the significant difference in the chemical composition by season noted in Table 3, it is of interest to examine variations in chemistry between seasons for specific transport patterns.

Seasonal differences in nss $\mathrm{SO}_{4}{ }^{*}$ are only associated with certain flow patterns. For example, the average per event deposition of nss $\mathrm{SO}_{4}{ }^{=}$associated with transport from the $\mathrm{SW}$ was $26 \mu \mathrm{eq} / \mathrm{m}^{2}$ in both seasons (Figure 14), with no significant difference in the distributions between seasons. In contrast, the carboxylic acids were significantly higher (factor of 2-3) in the warm season for this flow pattern. When transport from Madagascar was considered (Figure 15), there was a large (factor of 3 ) difference in the average per event deposition of nss $\mathrm{SO}_{4}{ }^{*}$ between seasons and a significant difference in concentration distributions.
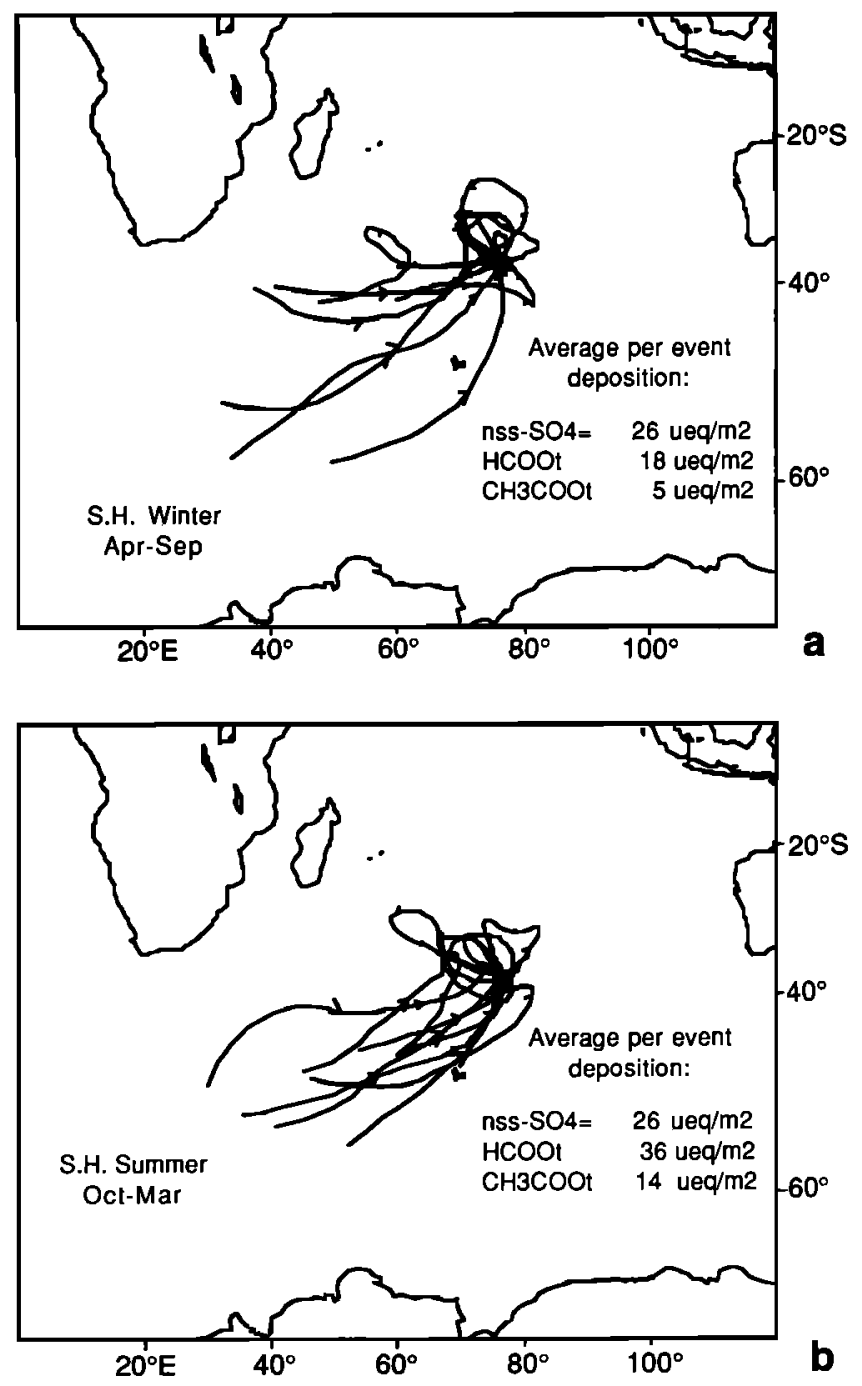

Fig. 14. Transport from the $\mathrm{SW}$ in both seasons indicating the average per event deposition of nss $\mathrm{SO}_{4}{ }^{2}, \mathrm{HCOO}_{t}$, and $\mathrm{CH}_{3} \mathrm{COO}_{4}$. 

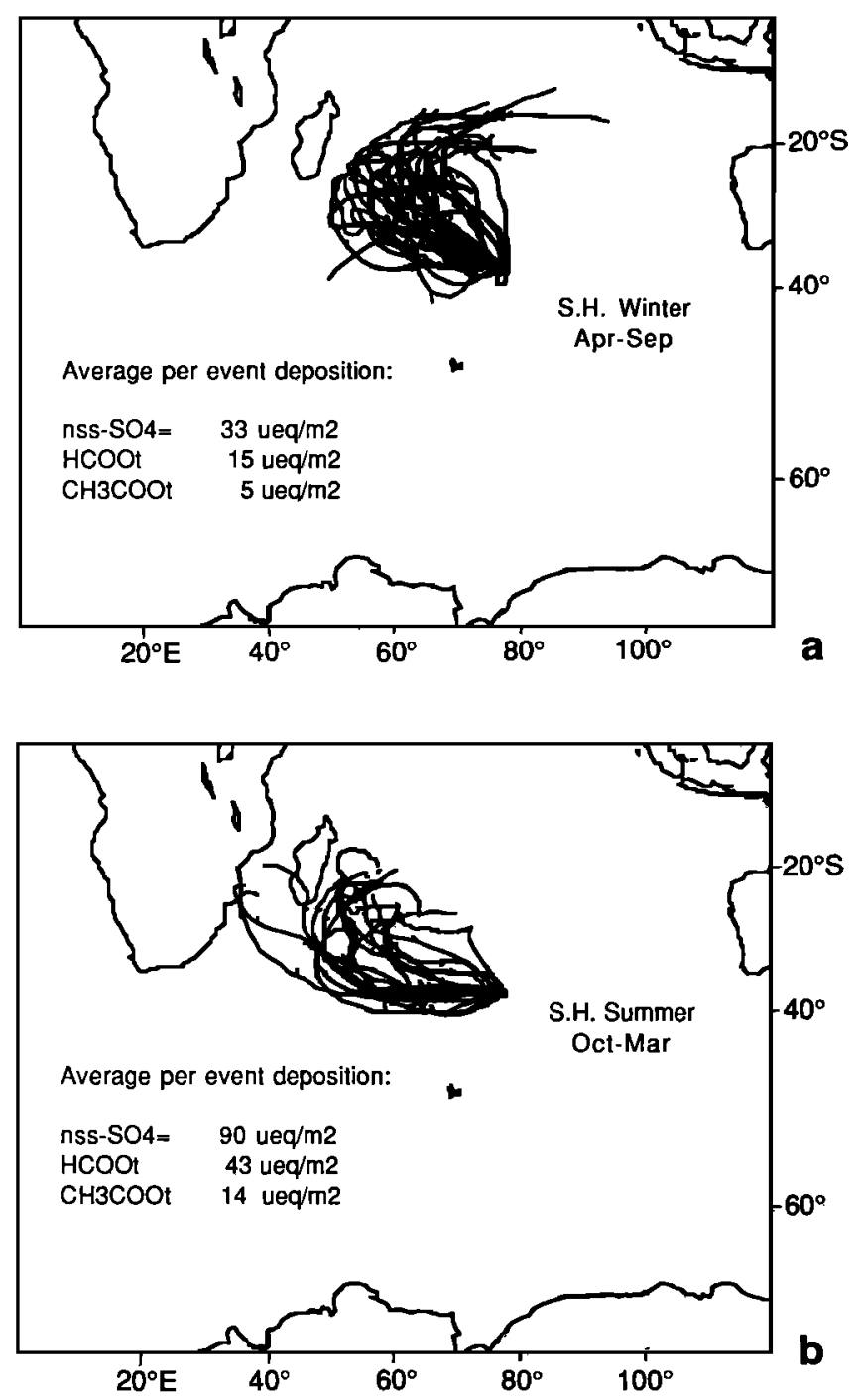

Figure 15. Transport from Madagascar in both seasons indicating the average per event deposition of nss $\mathrm{SO}_{4}{ }^{2}$, $\mathrm{HCOO}_{4}$, and $\mathrm{CH}_{3} \mathrm{COQ}_{4}$.

Again the carboxylic acids were also higher in the summer. These results suggest the sources for carboxylic acids are seasonally dependent and uniformally or relatively locally distributed. Sources for the nss $\mathrm{SO}_{4}{ }^{2}$, however, appear to be both seasonally dependent and "spatially" defined. These results are consistent with the hypothesis that concentrations of $\mathrm{nss} \mathrm{SO}_{4}{ }^{-}$are influenced by both a localized biogenic source and by a long-range transport from either anthropogenic continental sources or distant biogenic source regions.

\subsection{Radon as a Tracer of Long-Range Transport}

A plot of the trajectories corresponding to events classified as remote continental and remote oceanic indicates continental radon signals were generally associated with transport from the African/Madagascar region, while oceanic signals were associated with transport from the waters N or WSW (Figure 16) of the island. This correspondence between tracers suggests that
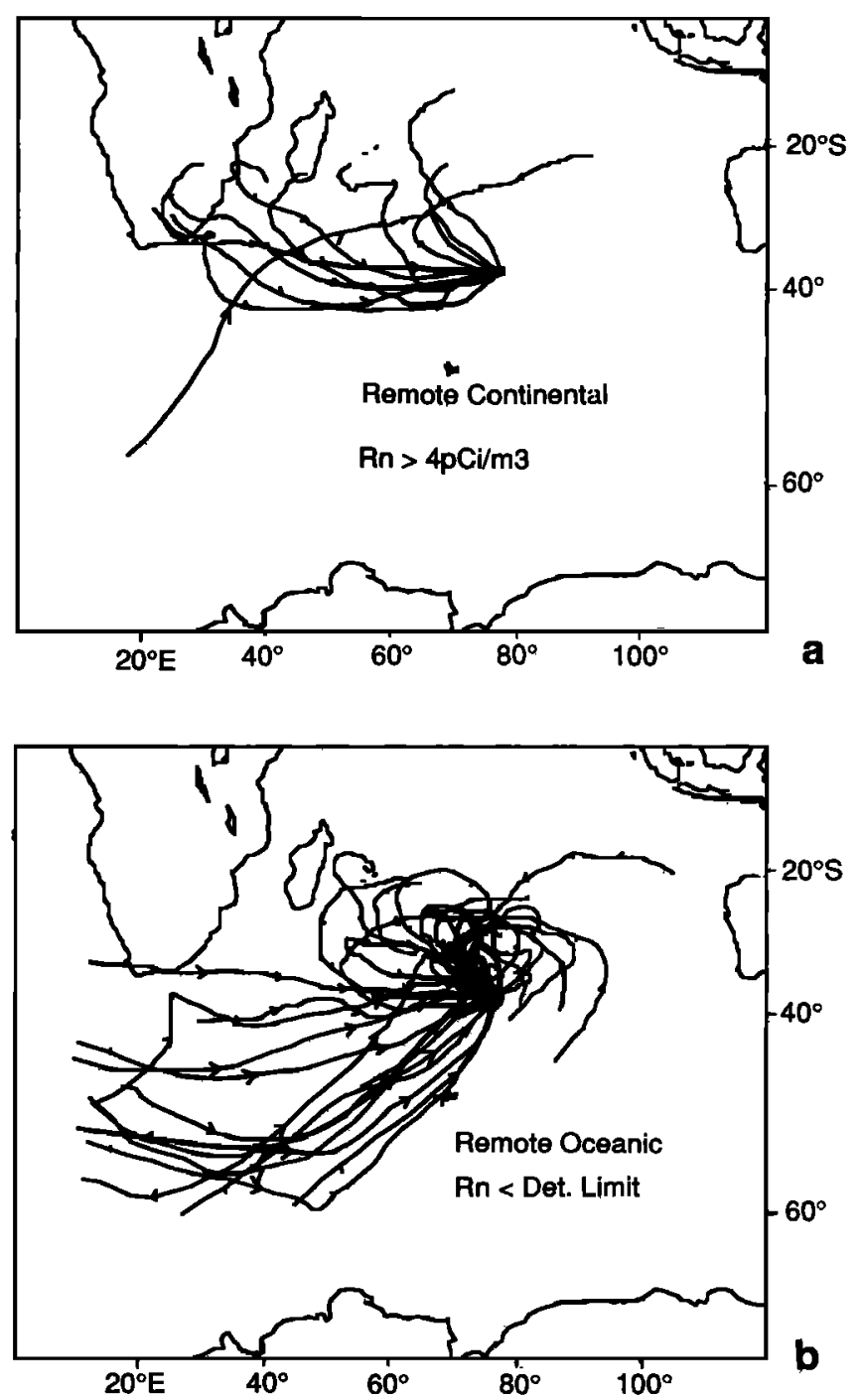

Fig. 16. The 850 mbar transport patterns for events classified as (a) remote continental and (b) remote oceanic, using ${ }^{222} \mathrm{Rn}$.

the $850 \mathrm{mbar}$ trajectories reasonably represent the level of radon transport. Lambert et al. [1982] found that most of the radonic storms occur with very rapid boundary layer transport between April and September, with a peak in June and July. Consistent with this are results obtained using radon in a general circulation model [Balkanski and $J a c o b, 1990$ ]. The model predicted a strong pressure gradient along the SE edge of the African continent, and the presence of a midlatitude low off the tip of southern Africa were the conditions which result in rapid advection of polluted boundary layer air from the African continent. These conditions occur most frequently during winter months when the subtropical high is closest to the Madagascar coast.

For the radonic storms classified in this study, $67 \%$ occurred during the cold season (April to September). Kruskal-Wallis comparisons of concentration and per event deposition distributions indicate that $\mathrm{NO}_{3}{ }^{-}$and nss $\mathrm{SO}_{4}{ }^{=}$were both significantly concentrated and deposited in remote continental air masses. There were no 
significant differences in distributions of per event precipitation amount or any of the other ions in precipitation. Figure 17 illustrates the concentration distributions of $\mathrm{NO}_{3}^{-}$, and nss $\mathrm{SO}_{4}{ }^{2}$, and precipitation amount by radon class. The greatest differences occur for $\mathrm{NO}_{3}^{-}$. This is reasonable given that most of the remote continental events occur during the winter, when nss $\mathrm{SO}_{4}{ }^{=}$ concentrations are lower and less variable to begin with.

Goudry et al: [ $[1983,1990]$ found that ${ }^{22} \mathrm{Rn}$ was an effective tracer for identifying $\mathrm{CO}_{2}$ emissions from southern Africa with peaks in ${ }^{222} \mathrm{Rn}$ and $\mathrm{CO}_{2}$ often correlated, and the greatest flux of $\mathrm{CO}_{2}$ occurring in August. Aerosols with an anthropogenic mineralogical composition measured on Amsterdam Island were also associated with high ${ }^{222}$ Rnconcentrations [Gaudichet et al., 1989]. These results suggest that radon is an effective air mass tracer and indicate that continental air can be detected $5000 \mathrm{~km}$ from southern Africa. The fact that the favored boundary layer transport conditions occur most frequently during southern hemispheric winter and early spring likely reduce the potential impact of southern African emissions on Amsterdam Island, since removal
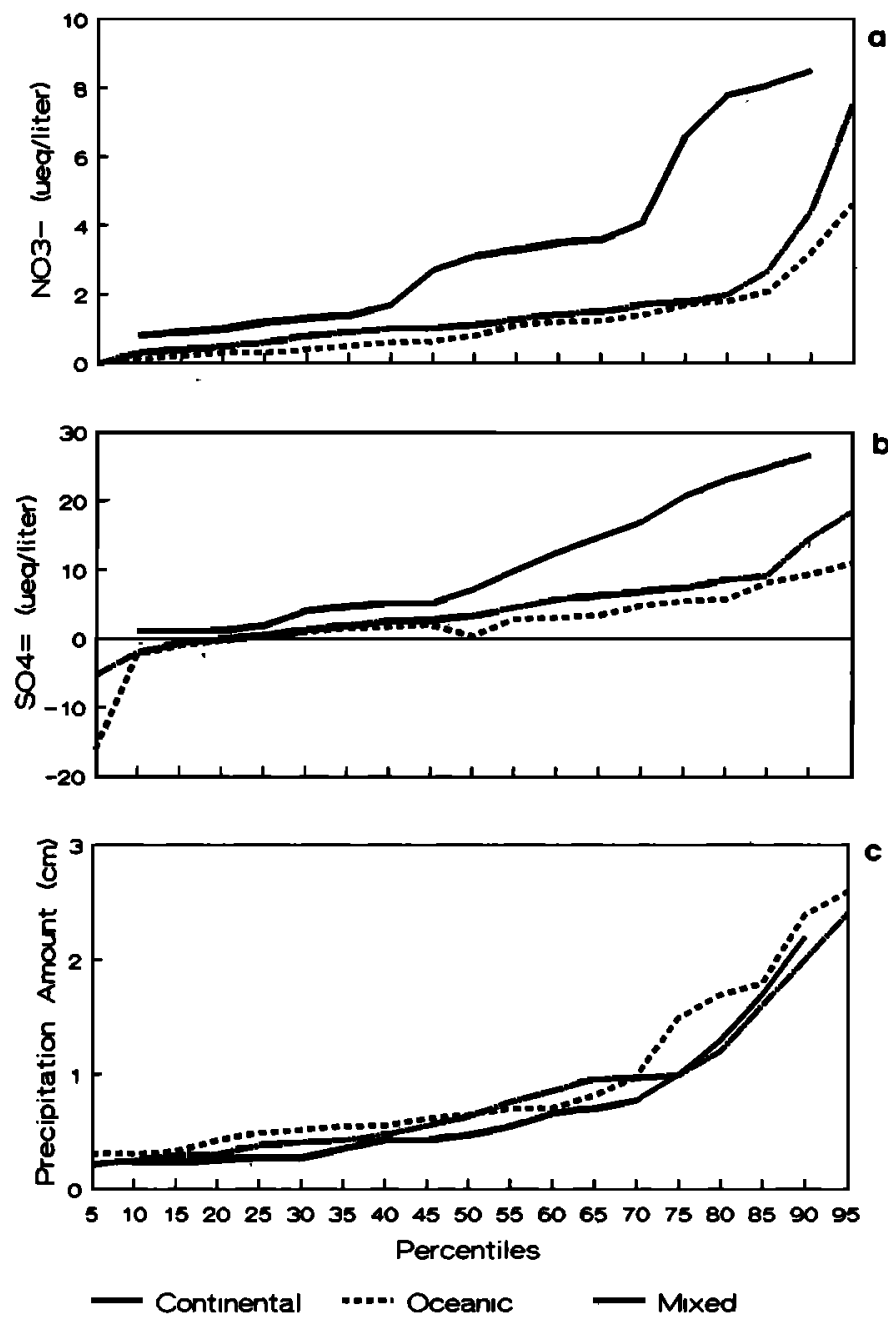

Fig. 17. Concentration distributions of (a) $\mathrm{NO}_{3}^{-}$,(b) nss $\mathrm{SO}_{4}^{-}$, and (c) precipitation amount by radon classification. conditions (surface wind speeds, wave heights and precipitation frequency) are maximized during this part of the year.

\section{Conclusions}

In conclusion, we find that precipitation on Amsterdam Island is composed of sea salt and a small but variable acid component. There is no apparent dominant acid, and results indicate that carboxylic acids, $\mathrm{H}_{2} \mathrm{SO}_{4}$, and perhaps $\mathrm{HCl}$ may contribute significantly to the acidity of precipitation at this remote location. Variability in composition was investigated over a range of temporal scales from annual to seasonal and within seasons based on differences in transport. Seasonal variability has been related to temporally varying source strength (e.g., marine biogenic sources for nss $\mathrm{SO}_{4}{ }^{2}$, carboxylic acids, and $\mathrm{NH}_{4}{ }^{+}$, and continental combustion sources for $\mathrm{NO}_{3}^{-}$, a portion of nss $\mathrm{SO}_{4}{ }^{*}$, and perhaps nss $\mathrm{Cr}$ ). Meteorologically-driven differences in "effective" source strength and source region have also been identified.

Within seasons, different transport patterns have been identified by cluster analysis. Variability with transport suggests the clusters defined by flow from Madagascar and southeast Africa and the NE are important source regions for $\mathrm{nss} \mathrm{SO}_{4}{ }^{2}$ and $\mathrm{NO}_{3}{ }^{-}$, although composition was variable even for events that arrive from similar regions. Radon was shown to be a useful tracer for $\mathrm{NO}_{3}{ }^{-}$transported from continental source regions during the cold season (AprilSeptember). Inter-annual variations in nss $\mathrm{SO}_{4}{ }^{2}$ appear to be related to variability in large-scale circulation as a result of air masses arriving from different source regions. These changes in circulation defined by different states of the Southern Oscillation may also affect source strength of DMS emissions through the variable influence of meteorological parameters like wind speed and sea surface temperature.

Given the variability in composition at even a remote site like Amsterdam Island, the characterization of concentrations or depositions as "background levels" should be treated carefully. The importance of marine processes in controlling the chemistry of nss $\mathrm{SO}_{4}{ }^{2}$, carboxylic acids, and nss $\mathrm{Cr}$ must be considered when comparing the precipitation composition of this location to continental regions. Furthermore, it is important to consider that extreme events can make a significant contribution to both average concentrations and total depositions. On the basis of transport patterns and tracers, there are conditions under which the impact of anthropogenic emissions from Africa can be identified on Amsterdam Island. Given that this continental influence varies seasonally, and potentially annually, suggests the need for the concept of a dynamic background composition. Recognizing that we can in fact account for the processes influencing observed variability, our results suggest Amsterdam Island is an excellent site for characterizing the composition of remote marine precipitation. 
Acknowlegments. This is a contribution to the Global Precipitation Chemistry Project, funded by the U.S. National Oceanic and Atmospheric Administraticn. This is contribution number 1206 of Centre des Faibles Radioactivites. We appreciate the contribution of Joyce Harris of NOAA who provided us with trajectory data. We are grateful to John Miller, Rick Artz, Sue Turner, Joe Prospero, and Yves Balkanski for comments on this manuscript. John Maben, Judy Montag, and Cheryl Bardwell assisted in UVA chemical analyses and data reduction, and special thanks to Brenda W. Morris who skillfully typeset this manuscript.

\section{References}

Bakanski, Y. J., and D. J. Jacob, Transport of continental air to the subantarctic Indian Ocean, Tellus, 42B, 1990.

Charlson, R. J., J. E. Lovelock, M. O. Andreae, and S. G. Warren, Oceanic phytoplankton, atmospheric sulphur, cloud albedo and climate, Nature, 32, 655-661, 1987.

Cicerone, R. J., Halogens in the atmosphere, Rev. Geophys. Space Phys., 19, 123-139, 1981.

Conover, W. J., Practical Nonparametric Statistics, 2nd ed., 493 pp, John Wiley, New York, 1980.

Crutzen, P. J., The global distribution of hydroxyl radical, in Atmospheric Chcmistry, edited by E. D. Goldberg, 1313-1328, Springer-Verlag, New York, 1982.

Fishman, J., C. E. Watson, J. C. Larsen, and J. A. Logan, Distribution of tropospheric ozone determined from satellite data, J. Geophys. Res., 95, 3599-3617, 1990.

Galloway, J. N., and A. Gaudry, The composition of precipitation on Amsterdam Island, Indian Ocean, Atmos. Environ., 18, 2649-2656, 1984.

Galloway, J. N., G. E. Likens, W. C. Keene, and J. M. Miller, The composition of precipitation in remote areas of the world, J. Geophys. Res., 87, 8771-8786, 1982.

Galloway, J. N., W. C. Keene, R. S. Artz, J. M. Miller, T. M. Church, and A. H. Knap, Processes controlling concentrations of $\mathrm{SO}_{4}{ }^{*}, \mathrm{NO}_{3}^{-}, \mathrm{NH}_{4}^{+}, \mathrm{H}^{+}, \mathrm{HCOO}_{\mathrm{t}}$ and $\mathrm{CH}_{3} \mathrm{COO}_{4}$ in precipitation on Bermuda, Tellus, $41 \mathrm{~B}$, 427-443, 1989.

Gaudichet, A., R. Lefevre, A. Gaudry, B. Ardouin, G. Lambert, and J. M. Miller, Mineralogical composition of aerosols at Amsterdam Island, Tellus, 41B, 344-352, 1989.

Gaudry, A., J. M. Asencio, and G. Lambert, Preliminary study of $\mathrm{CO}_{2}$ variations at Amsterdam Island (Territoire des Terres Australes et Antarctiques Francaises), $J$. Geophys. Res., 88, 1323-1329, 1983.

Gaudry, A., G. Polian, B. Ardouin, and G. Lambert, Radon-calibrated emissions of $\mathrm{CO}_{2}$ from South Africa, Tellus, 42B, 11-21, 1990.

Gordon, A. D., Classification, Methods for the Exploratory Analy sis of Mutlivariate Data, 193 Fp., Chapman and Hall, London, 1981.

Harris, J. M., The GMCC atmospheric trajectory program, NOAA Tech. Memo., ERL/ARL-116, 1982.

Harris, J. M., and J. D. Kahl, A descriptive atmospheric transport climatology for the Mauna Loa Observatory using clustered trajectories, J. Geophys. Res., 95, 13,651-13,667, 1990.

Jouventin, P., J. C. Stahl, H. Weimerskirsch, and J.L. Mougin, The seabirds of the French subantarctic islands and Adelie
Land, their status and conservation, in Status and Conservation of the Worlds Seabirds, edited by J. P. Croxall, P. G. Evans and R. W. Schreiber, ICBP Technical Pub. 2, 1983.

Kahl, J. D., and P. J. Samson, Uncertainty in trajectory calculations due to low resolution meteorological data, $J$. Clin. Appl. Meteorol., 25, 1816-1831, 1986.

Kalkstein, L. S., G. Tan, and J. A. Skindelov, An evaluation of three clustering procedures for use in synoptic climatological classification, J. Clim. Appl. Metcorol., 26, 717-730, 1987.

Keene, W. C., and J. N. Galloway, Organic acidity in precipitation of North America, Atmos. Environ., 18, 2491-2497, 1984.

Keene, W. C., and J. N. Galloway, The biogeochemical cycling of formic and acetic acids through the troposphere: An overvicw of current understanding, Tellus, $40 B$, 322-334, 1988.

Kcene, W. C., J. N. Galloway, and J. D. Holden, Jr., Measurement of weak organic acidity in precipitation from remote areas of the world, $J$. Geophys. Res., 88 , 5122-5130, 1983.

Keene, W. C, A. A. P. Pszenny, J. N. Galloway, and M. E. Hawley, Sea-salt corrections and interpretation of constituent ratios in marine precipitation, J. Geophys. Res., 91, 6647-6658, 1986.

Keene, W. C., A. A. P. Pszenny, D. J. Jacob, R. A. Duce, J. N. Galloway, J. J. Schultz-Tokos, H. Sievering, and J. F. Boatman, The geochemical cycling of reactive chlorine in the marine troposphere, Global Biogeochem. Cycles, 4, 407-430, 1990.

Kritz, M. A., and J. Rancher, Circulation of $\mathrm{Na}, \mathrm{Cl}$, and $\mathrm{Br}$ in the tropical marine atmosphere, J. Geopinys. Res., 85, 1633-1639, 1980.

Lambert, G., G. Polian, and D. Taupin, Existence of periodicity in radon concentrations and in large scale circulation at lower altitude between $40^{\circ}$ and $70^{\circ}$ degrees S, J. Geophys. Res., 75, 2341- 2345, 1970.

Lambert, G., G. Polian, J. Sanak, B. Ardouin, A. Buisson, A. Jegou, and J. C. Le Roulley, Radon and daughter products cycle: Application to troposphere-stratosphere exchanges, Ann. Geophys., 38, 497-531, 1982.

Legrand, M. R., and R. J. Delmas. Relative contributions of tropospheric and stratospheric sources to nitrate in Antarctic snow, Tellus, 38B, 236-249, 1986.

Levy, H. II, and W. J. Moxim. Simulated global distribution and deposition of reactive nitrogen emitted by fossil fuel combustion, Tellus, 41B, 256-271, 1989.

Levy, H., II., J. D. Mahlman, and W. J. Moxim. A stratospheric source of reactive nitrogen in the unpolluted troposphere, Geophys. Res. Lett., 7, 441-444, 1980.

Likens, G. E., W. C. Keene, J. M. Miller, and J. N. Galloway. Chemistry of precipitation from a remote, terrestrial site in Australia, J. Geophys. Res., 92, 13,299-13,314, 1987.

Meehl, G., The annual cycle and interannual variability in the Tropical Pacific and Indian Ocean regions, Mon. Weather Rev., 115, 27-50, 1987.

Miller, J. M., The use of back air trajectories in interpreting atmospheric chemistry data: A review and bibliography, NOAA Tech. Memo. ERL/ARL-155, 28 pp., 1987.

Moody, J. L. The influence of meteorology on precipitation chemistry at selected sites in the eastern United States, 
Ph.D. dissertation, Univ. of Mich., Univ. Microfilms Int., Ann Arbor, Mich., 1986.

Moody, J. L., and J. N. Galloway, Quantifying the influence of atmospheric transport on the composition of precipitation on Bermuda, Tellus, 40, 463-479, 1988.

Moody, J. L., and P. J. Samson, The influence of atmospheric transport on precipitation chemistry at two sites in the midwestern United States, Atmos. Environ., 23, 2117-2132, 1989.

Nguyen, B. C., S. Belviso, N. Mihalopoulos, J. Gostan, and P. Nival, Dimethyl sulfide production during natural phytoplanktonic blooms, Marine Chemistry, 24, 133-141, 1988.

Nguyen, B. C., N. Mihalopoulos, and S. Belviso, Seasonal variation of atmospheric dimethylsulfide at Amsterdam Island in the southern Indian Ocean, J. Atmos. Chem., 8, 1990.

Norusis, M. J., SPSS-X Advanced Statistics Guide, 505 pp., SPS Inc., Chicago, Il., 1985.

Philander, S.G. H., El Nino, La Nina, and the Southern Oscillation, 263 pp., Academic Press, San Diego, Calif., 1990.

Polian, G., G. Lambert, B. Ardouin, and A. Jegow, Longrange transport of continental radon in subantarctic and antartic areas, Tellus, 38B, 178-189, 1986.

Quinn, P. K., T. S. Bates, and J. E. Johnson, Interactions betwen the sulfur and reduced nitrogen cycles over the central Pacific Ocean, J. Geophys. Res., 95, 16,40516,416, 1990.

Ramage, C. S., Climate of the Indian Ocean north of 35 degrees S., in World Survey of Climatology, 15, 603-674, Elsevier, Amsterdam, 1984.

Rasmussen, E. M., and P. A. Arkin, Measuring and understanding global precipitation variability. Paper presented at Symposium on Global Change Systems, Am. Meteorol. Soc., Anaheim, Calif., February 5-9, 1990.

Rasmussen, E. M., and J. M. Wallace, Meteorological aspects of the El Nino/Southern Oscillation, Science, 222, 1195, 1983.

Romesburg, C. H. Cluster Analysis for Researchers, 334 pp., Lifetime Learning Publications, Belmont, Calif., 1984.

Roux, J. P., and R. D. Hes, The seasonal haul-out cycle of the fur seal Arcterophalus Tropicalis on Amsterdam Island, Mammilia, 148, 377-389, 1984.

Stackpole, J., The NMC 9-layer global primitive equation model on a latitude-longitude grid, NMC Office Note 178, 31 pp., Nat. Meteorol. Cent., Suitland, MD., 1978.

Taljaard, J. J. and H. Van Loon, Climate of the Indian Ocean South of 35 degrees S, in World Survey of Climatology, 15, 508-591, Elsevier, Amsterdam, 1984.

Tyson, P. D., F. J. Druger, and C. W. Louw, Atmospheric pollution and its implications in the Eastern Transvaal Highveld, Rep. 15, 114 pp., S. Afri. Nat. Sci. Progranimes Report, 1988.

Walker, G. T., and E. W. Bliss, World weather, IV, Mem. Roy. Meteorol. Soc., 3, 81-95, 1930.

Whelpdale, D. M. and J. L. Moody, Overviews of long-range transport, in The Long-Range Atmospheric Transport of Natural and Contaminant Substances, edited by A. H. Knap (ed.), NATO ASI Series, 3-36, Kluwer Academic Publ., Dordrecht, 1990.

Wilson, T. R. S., Salinity and the major elements of seawater, in Chemical Oceanography, vol. 1, 2nd ed., edited by J. P. Riley and G. Skirrow, 365-413, Academic, Orlando, Fl., 1975.

J.N. Galloway, W.C. Keene, and J.L. Moody, Department of Environmental Sciences, Clark Hall, University of Virginia, Charlottesville, VA 22903.

A. Gaudry and G. Polian, CNRS/Centre des Faibles Radioactivités avenue de la Terrasse, 91198 Gif-sur-Yvette, France.

A.A.P. Pszenny, NOAA/AOML, 4301 Rickenbacker Cswy, Miami, FL 33149.

(Received July 5, 1990;

Revised July 19, 1991;

Accepted July 19, 1991.) 